\title{
Progress in faunal correlation of Late Cenozoic fluvial sequences 2000-4: the report of the IGCP 449 biostratigraphy subgroup
}

\author{
D.C. Schreve ${ }^{\mathrm{a}, *}$, D.H. Keen ${ }^{\mathrm{b}, *}$, N. Limondin-Lozouet ${ }^{\mathrm{c}}$, P. Auguste ${ }^{\mathrm{d}}$, Juan I. Santisteban ${ }^{\mathrm{e}}$, \\ M. Ubilla ${ }^{\text {f }}$ A. Matoshko ${ }^{\text {g }}$, D.R. Bridgland ${ }^{\text {h }}$, R. Westaway ${ }^{\mathrm{i}}$ \\ ${ }^{a}$ Department of Geography, Royal Holloway University of London, Egham, Surrey TW20 OEX, UK \\ ${ }^{\mathrm{b}}$ Institute of Archaeology \& Antiquity, The University of Birmingham, Edgbaston, Birmingham B15 2TT, UK \\ ${ }^{\mathrm{c}}$ Laboratoire de Géographie Physique, UMR CNRS 859, 1 Place Aristide Briand, 92195 Meudon cedex, France \\ ${ }^{\mathrm{d}}$ UMR 8014 CNRS, Laboratoire de Paléontologie et Paléogéographie du Paléozoïque, Université des Sciences et Technologies de Lille 1, \\ F-59655 Villeneuve d'Ascq Cedex, France \\ e Departamento Estratigrafía, Facultad Ciencias Geológicas, Universidad Complutense de Madrid, Calle José Antonio Nováis 2, 28040 Madrid, Spain \\ f Paleontología, Ingepa, Facultad de Ciencias, Universidad de la República, Iguá 4225, 11400 Montevideo, Uruguay \\ ${ }^{\mathrm{g}}$ Institute of Geography, National Academy of Sciences of Ukraine, 44 Volodymyrska Street, 01034 Kiev, Ukraine \\ ${ }^{\mathrm{h}}$ Geography Department, Durham University, Durham DH1 3 LE, UK \\ ${ }^{\mathrm{i}}$ Faculty of Mathematics and Computing, The Open University, Eldon House, Gosforth, Newcastle upon Tyne NE3 3PW, UK
}

\begin{abstract}
Vertebrate and invertebrate faunal biostratigraphy is a well-tested method for establishing relative chronologies for fluviatile sequences that has proved useful in many parts of the world. The robust bones and teeth of large mammals are commonly found in fluviatile deposits, whereas small vertebrates can be readily recovered through systematic sieving of calcareous sediments, as can molluscs, the other major faunal group that has been used for biostratigraphical analysis of fluvial sequences. Because of their rapid and quantifiable rates of evolution, extinction, body mass change and dispersal during the Late Cenozoic, mammals are especially useful for ordering the fragmentary terrestrial sequence of interglacials and glacials, and proposing correlation with the global marine climatostratigraphic record. Other groups (e.g. reptiles and amphibians, ostracods) are as yet only in the initial stages of development as a dating tool, whereas some (e.g. fish, birds) still require substantial development in order to fully explore their utility. As part of IGCP 449, vertebrate and molluscan assemblages have made important contributions to datasets from a number of areas, notably northern France, central Germany, the Czech Republic and the Ukraine. Further south, mammalian assemblages have proved useful in separating discrete periods of climatic change in Iberia and Syria. At greater distances from the core area of fluvial biostratigraphical archives, significant contributions have come from South America (Uruguay River), South Africa (Vaal) and Australia (Riverine Plain and Lake Eyre drainage basin).
\end{abstract}

\section{Introduction}

There is a long tradition of studying fossils found in fluvial deposits and of using these fossil assemblages for relative dating (e.g. Kennard and Woodward, 1897;

\footnotetext{
*Corresponding author. Tel.: + 44 1784443569; fax: + 441784472836.

E-mail addresses: Danielle.Schreve@rhul.ac.uk (D.C. Schreve), limondin $(a)$ cnrs-bellevue.fr (N. Limondin-Lozouet),

Patrick.Auguste@univ-lille1.fr (P. Auguste), ubilla@fcien.edu.uy (M. Ubilla),matoshko@iptelecom.net.ua (A. Matoshko).
}

Kennard, 1924; Zeuner, 1945, 1946; Pike and Godwin, 1953; Sutcliffe, 1964; Kerney, 1971; Kahlke, 1975). A subgroup of IGCP participants undertaking this type of research was formed at the inaugural meeting in Prague (April 2001) and has compiled data on faunal assemblages from fluvial sequences in different parts of the world. Many different types of fossils can be found in fluvial sequences, from tree trunks and large animal bones in coarse gravels to pollen and other microfossils in fine-grained sediments. Although palynological studies have been of great importance since the first interglacials were defined (e.g. West, 
1956, 1957, 1980; Zagwijn, 1973; Turner, 1975) the resolution of pollen sequences in fluvial sequences is rarely sufficient for reliable age control (cf. Turner, 1985; Thomas, 2001), a problem that led to much historical controversy between palaeobotanists and other palaeontologists about the number and identity of interglacials in NW Europe (cf. Sutcliffe, 1964, 1975; Shotton, 1983; Bowen et al., 1989; Bridgland, 1994; Gibbard, 1994; Preece, 1995a, 1999; Schreve, 2001a). In essence, those working with animal fossils, particularly molluscs and mammals, were able to distinguish a greater number of interglacials and interstadials within the Middle and Late Pleistocene than the palynologists. With increasingly convincing correlation between the marine oxygen isotope record and terrestrial sequences such as those in river valleys, and supported by geochronological methods wherever possible, it is the version of the Quaternary based on mammals and molluscs that has become for many the status que (cf. Bowen et al., 1989; Bowen, 1999; Schreve, 2001a, b; Bridgland and Maddy, 2002).

Both vertebrate and molluscan fossils are better preserved in areas of calcareous ground water, which generally coincide with limestone bedrock outcrops. Thus, fluvial deposits overlying the Chalk of NW Europe are often highly fossiliferous, whereas those in adjacent areas overlying non-calcareous Tertiary sands and clays are largely barren. Similarly, the Permian Muschelkalk outcrops in Central Germany coincide with abundant preservation of molluscan and vertebrate fossils in the fluvial terraces of rivers such as the Neckar, Ilm and Wipper, often within subaerial travertines interbedded with the fluvial sediments (Bridgland et al., 2004; see Figs. 1 and 2). Again, fluvial deposits on non-calcareous crystalline rocks, sand(stone)s and clays are generally lacking in useful fossils. The IGCP project has facilitated comparison of such records over wide areas, as will be demonstrated in this paper, which seeks to review and compare the more significant faunal records examined.

In the core area of IGCP 449, NW and Central Europe, the use of mammals and molluscs for biostratigraphy is well established (e.g. Ložek, 1964a, b; Stuart, 1982; Horacek and Ložek, 1988; Horacek, 1990; Keen, 1990; Kolfschoten, 1990, 2000; Kovanda et al., 1995; Preece, 1995a, 1999; Meijer and Preece, 2000), with mammalian assemblages proving particularly useful for distinguishing the four main post-Elsterian/Anglian interglacials (Schreve, 2001a; Bridgland and Schreve, 2001, 2004; Schreve and Bridgland, 2002; Bridgland et al., 2004). In pre-Elsterian contexts, a combination of mammalian and molluscan signatures has been used to unravel the complexity of short-lived warm events within the Cromerian Complex (Kolfschoten and Turner, 1996; Preece and Parfitt, 2000; Stuart and Lister, 2001). Distinctive taxa have also proved useful in distinguishing certain episodes, for example the presence in MIS 11 of Retinella (Lyrodiscus) elephantium, an extinct member of the Zonitidae belonging to a genus today restricted to the Canary Islands (Rousseau, 1992; Rousseau et al., 1992;

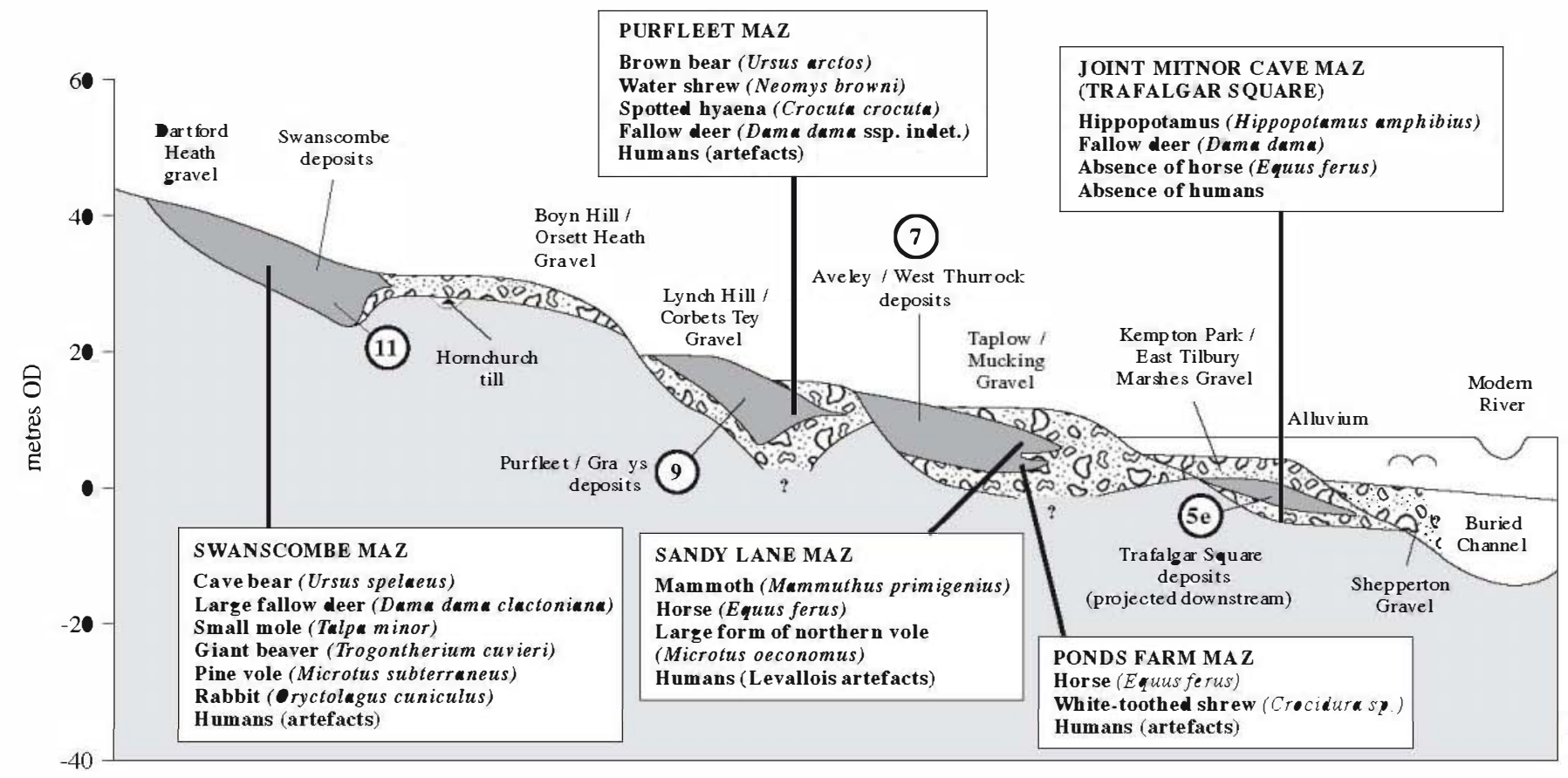

(11) Numbers indicate the oxy gen i sotope st ages Iu terglacial deposits

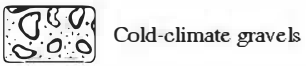

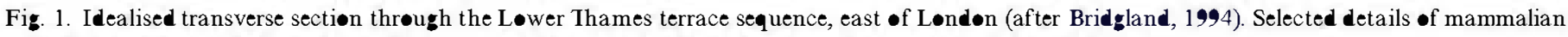

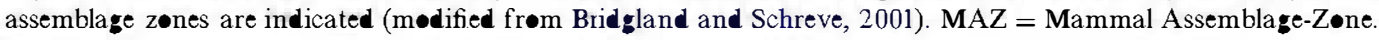




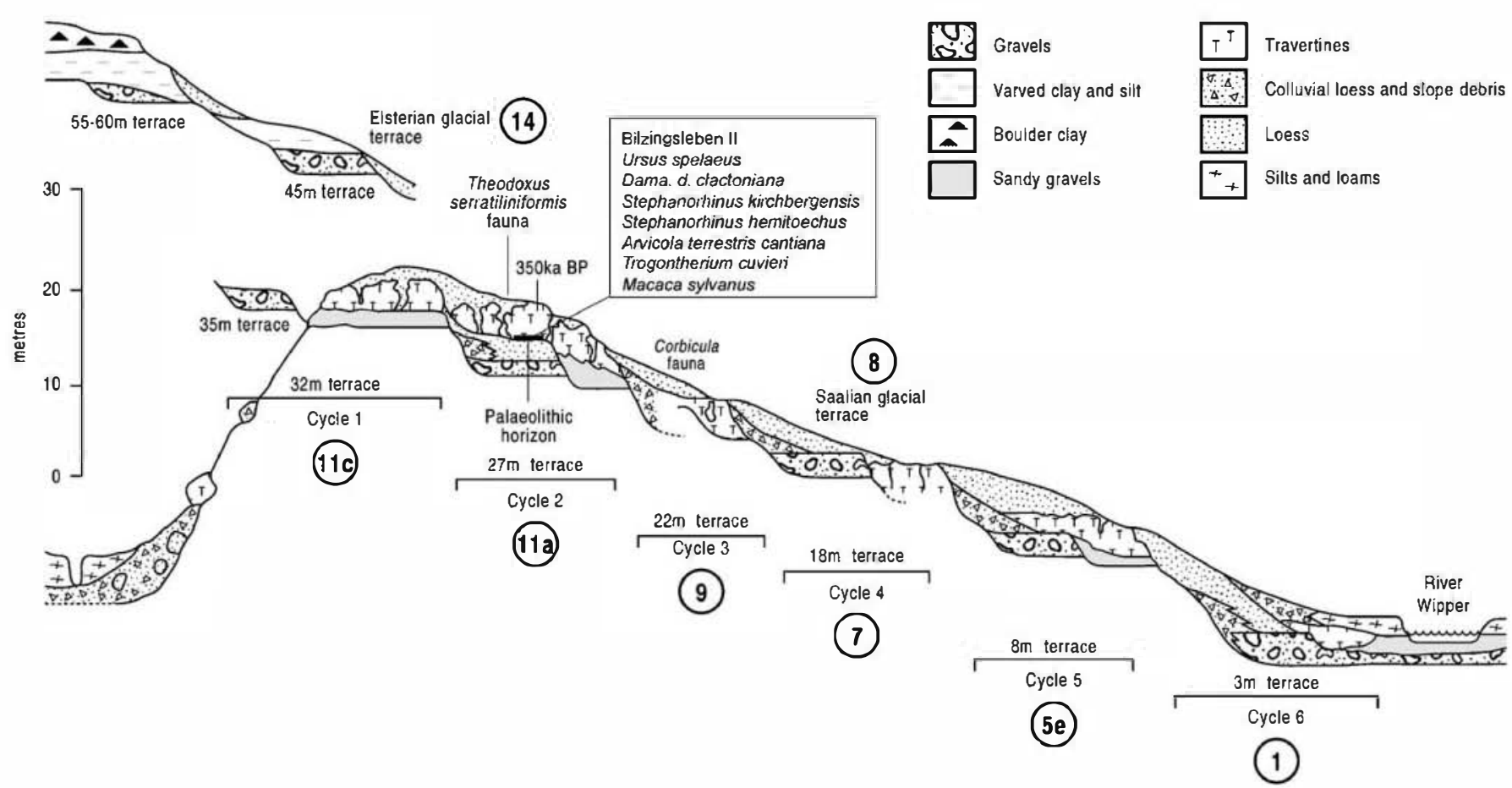

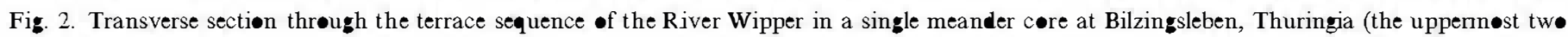

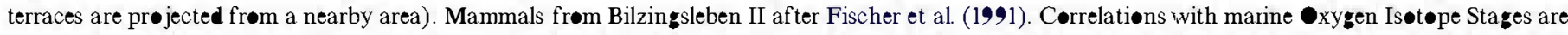
suggested and the positions of the depøsits correlated with the Elsterian (Elster I) and Saalian glaciations are indicated. Modified from Bridgland et al. (2004).

Antoine and Limondin-Lozouet, 2004; Preece et al., 2006, 2007) and the widespread occurrence of Hipp•p•tamus amphibius in the Last Interglacial (MIS 5e) (Stuart, 1982; Currant and Jacobi, 2001).

\section{Correlation within NW \& C. Enrope}

Inevitably (given the pedigree of research and plethora of sites, both new and historical) this, the core area of IGCP 449 , has provided the bulk of the biostratigraphical data compiled by the subgroup. A number of previous IGCP 449 reviews have used mammalian biostratigraphy as a means for correlating fluvial deposits within NW and central Europe (Schreve and Bridgland, 2002; Bridgland and Schreve, 2004; Bridgland et al., 2004), based on comparison with the succession of British Mammal Assemblage Zones (MAZs) established by Schreve (2001a,b). This was based on four discrete mammalian groupings considered to represent the four post-Anglian interglacials, with an additional subdivision of the penultimate stage thought to reflect pulses of faunal turnover at the sub-Milankovitch level. The groupings are correlated with MIS 11/Hoxnian Interglacial (Swanscombe MAZ), MIS 9 (Purfleet MAZ), MIS 7 (Ponds Farm MAZ and Sandy Lane MAZ) and MIS 5e/Ipswichian Interglacial (Joint Mitnor Cave MAZ see Currant and Jacobi, 2001). The principal mammalian characters of each grouping are indicated in Table 1 and Fig. 1. They have been matched to the four interglacial members within the Lower Thames terrace staircase (Bridgland, 1994; Bridgland and Schreve, 2001, 2004; Schreve, 2001a, 2001b; Bridgland et al., 2004). Furthermore, the development of high-precision MC ICP MS uranium-series age-estimates at correlated sites has allowed the testing and confirmation of ideas concerning small-scale environmental change and faunal turnover at the isotopic substage level (Candy and Schreve, 2007). For further details the reader is referred to the above references.

\subsection{Britain and Germany}

Key Lower Thames sites published during the course of IGCP 449 include three localities attributed to MIS 9: Barling (Bridgland et al., 2001), Purfleet (Schreve et al., 2002) and Hackney Downs (Green et al., 2005), and two attributed to MIS 7: Aveley (Bridgland et al., 2003a; Schreve, 2001a, 2004) and Lion Pit tramway cutting, West Thurrock (Schreve et al., 2006). Data from these sites both test and reinforce the biostratigrahical model erected by Schreve (2001a; Fig. 1, Table 1).

Distinctive molluscan assemblages also occur within the Lower Thames sequence and can further assist in constraining the age of these deposits (Table 1). In the Swanscombe interglacial deposits, attributed to MIS 11, an important feature of the molluscan record is the appearance, part-way through the sequence there, of an exotic, central and southern European suite of Mollusca, typified by species such as Theodoxus serratiliniformis 
Table 1

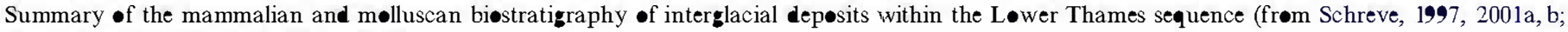
Currant and Jacobi, 2001; Keen, 2001)

Swanscombe MAZ MIS 11

Purfleet MAZ MIS,

P॰nds Fm MAZ, MIS $7 e / 7 c$

Sandy Lane MAZ MIS 7a
Key sites in the Thames Swansc $\bullet$ me Clact $\bullet n-\bullet$-Sea Key sites elsewhere Høxne

Key sites in the Thames Grays Purfleet

Key sites elsewhere Cudmøre Grøve

Key sites in the Thames Aveley

Key sites in the Thames Aveley Stantøn Harcourt Crayf ord Key sites elsewhere, Ilf ord, Marsworth Løwer Channel
Mammalian signature

- FAD in Britain of Stephanorhinus hemitoechus, Stephanorhinus kirchbergensis, Megaloceros giganteus, Bos primigenius and Equus hydruntinus

- Unique appearance of Ursus spelaeus and Dama dama clactoniana

- LAD in Britain of Talp minor, Trogontherium cuvieri, Oryctolagus cuniculus and Microtus (Terricola) subterraneus

- Presence of Arvicola terrestris cantian with mean SDQ 140. Archaic 'Mimomys føld' present at løw t• medium frequency $(<40 \%)$

- Important absences: Crocuta crocut and Hippopotamus amphibius

Molluscan signature

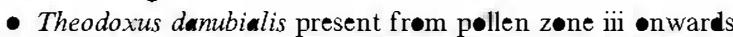

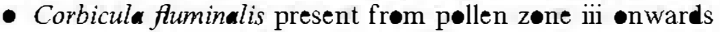

Archaeølegical signature

- Early inter lacial characterised by Clactønian flake and core industry

- Later parts of interglacial characterised by Acheulean handaxe industry

Mammalian signature

- FAD in Britain of Ursus arctos and Dama dama cf. dama

- Reappearance in Britain of Crocuta crocuta

- Presence of the morphotype 'Neomys browni'

- LAD in Britain of Macaca sylvanus

- Presence of Arvicola terrestris cantian with mean SDe 130. Rare 'Mimomys føld'

- Important absence: Hippopotamus amphibius

Molluscan signature

- Absence of Theodoxus danubialis in the Thames

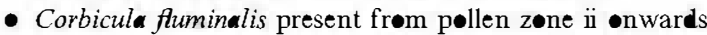

Archaeølegical signature

- Early inter lacial characterised by Clactonian flake and core industry

- Later parts of inter lacial characterised by Acheulean handaxe industry

- Final interglacial characterised by Middle Palaeølithic Levalløis industry

Mammalian signature

- Early interglacial predominantly woodland episede

- Presence of Palaeoloxodon antiquus, Crocidura and Equus ferus

- Presence of Arvicola terrestris cantiana with mean SDQ 120. 'Mimomys føld' absent

Mølluscan signature

- Corbicula fluminalis present frøm pøllen zøne ii

Archaeølogical signature

- Hominins present but record currently to॰ sparse to attribute to industry

Mammalian signature

- Later interglacial pred॰minantly •pen grassland episede

- Abundance of late mørph $\bullet$ type of Mammuthus trogontherii, later replaced by $M$. primigenius

- Abundance of Equus ferus, Stephanorhinus hemitoechus, Bos primigenius and Cervus elaphus

- Presence of Arvicola terrestris cantian with mean SDQ 120

- Presence of large-bødied Microtus oeconomus

- LAD •f Stephanorhinus kirchbergensis and Apodemus maastrichtiensis

- Important absences: Dama dama, Hippopotamus amphibius 
Molluscan signature

- Corbicula fluminalis present thrøughøut

- LAD of Paladilhia radigueli and Pisidium clessini

Archaeølegical signature

- Levalløis industry

\begin{tabular}{|c|c|}
\hline \multirow{3}{*}{$\begin{array}{l}\text { Jøint Mitnør } \\
\text { Cave MAZ, MIS } \\
\text { se }\end{array}$} & Key sites in the Thames Trafalgar \\
\hline & Square Brentford \\
\hline & $\begin{array}{l}\text { Key sites elsewhere Barringtøn } \\
\text { Jøint Mitnør Cave }\end{array}$ \\
\hline
\end{tabular}

Mammalian signature

- Presence of Hippopotamus amphibious

- Abundance of Palaeoloxodon antiquus, Dama dama and Stephanorhinus hemitoechus

- Presence of Arvicola terrestris terrestris with mean SDQ 110.

- Absence of Stephanorhinus kirchbergensis and Equus ferus

Molluscan signature

- Corbicula fluminalis absent from Britain

Archaeølogical signature

- Hominins absent frøm Britain

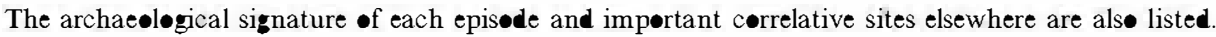

( = danubialis), Corbicula fluminalis, Belgrandia marginata and Unio crassus (Kennard, 1938; Kerney, 1971). Termed 'Rhenish', this suite has been attributed to a connection with the Rhine, perhaps related to a fall in sea level that reconnected Britain and mainland Europe, following brief separation early in the interglacial (White and Schreve, 2000). A molluscan assemblage containing $T$. serratininiformis has also been noted in the highest terrace of the post-Elsterian River Wipper (Fig. 2), in central Germany, correlated with the Holsteinian (Mania, 1995).

In contrast to the mammalian record, the molluscan signature of the MIS 9 interglacial in some NW European fluvial sequences is not readily separable from that of MIS 11 , although the timing of the appearance of the bivalve $C$. fluminalis has been cited as a criterion for distinguishing these episodes in the Thames system. This distinctionrequires the co-occurrence of a detailed pollen zonation in order to position the sequence in terms of pre temperate, early temperate, late temperate and post-temperate pollen biozones (i, ii, ii and iv, respectively; cf. Turner, 1970). During MIS 9, C. fluminalis appears in Zone ii at sites such as Barling, in the lowermost Thames valley north of Southend-on-Sea, whereas it is unknown before Zone iii in the MIS 11 sequences at Swanscombe and Clacton (Bridgland et al., 2001) (Table 1). New work during the IGCP 449 period at Hackney Downs, in East London, recorded a rich molluscan assemblage including a number of biostratigraphically significant species, dominated by $C$. fluminalis and Belgrandia marginata and including Pisidium clessini and Unio crassus, the last-named known in western Europe only prior to MIS 8 (Preece, 1999; Keen, 2001).

The MIS 7 interglacial also has a characteristic suite of Mollusca, found in the Lower Thames sites such as Crayford (Kennard, 1944), Aveley (Cooper, 1972) and the Lion Pit tramway cutting at West Thurrock (Bridgland and Harding, 1994; Schreve et al., 2006), as well as beyond the Thames basin. It is dominated by $C$. fluminalis, which is present in the Thames for the last time and contains a further important indictor in the form of $\boldsymbol{P}$. clessini, which is thought to have become globally extinct after MIS 7 (Keen, 1990, 2001; Preece, 1999). Similarly Paladilhia radigueli, a hydrobiid with brackish affinities that was present in older interglacials, also makes its last appearance in MIS 7 assemblages (Preece, 1995a) (Table 1). Deposits of this age also have a coleopteran fauna that is highly distinctive, not only in its species composition, but also in its indication of summer temperatures no warmer than those of the present, in marked contrast to the exotic southern European suite of species invariably found in Last Interglacial (MIS 5e) and MIS 9 deposits (Keen et al., 1999; Coope, 2000, 2001; Gao et al., 2000; Bridgland et al., 2001; Green et al., 2005). Some of the key evidence in this cited work is from rivers flowing into the basin of the Wash in eastern England, including the Nene, the Great Ouse and the Cam, all of which have fossiliferous sites within their Pleistocene sequences (see also Worssam and Taylor, 1969; Bridgland and Schreve, 2001).

Ipswichian Interglacial (MIS 5e) molluscan assemblages are characterised by the presence of species indicative of climates warmer than the present day (ca $23^{\circ} \mathrm{C}$ higher) and, in the UK, of a more continental climate (Keen, 1990; Keen et al., 1999). B. marginata is widespread but C. fluminalis is apparently absent (Table 1), despite apparently suitable environmental conditions and its reputation as a rapid coloniser. Its absence from the UK and the Netherlands during MIS Se therefore appears a genuine occurrence (Meijer and Preece, 2000). 
Following on from the recognition of increased palaeoclimatic complexity in the Cromerian Complex, based on the number of temperate episodes recognised in the stacked sequences in boreholes from the Netherlands (Zagwijn, 1985, 1996), the molluscan and mammalian biostratigraphy of the early Middle Pleistocene has also been thoroughly overhauled (Preece and Parfitt, 2000; Preece, 2001; Stuart and Lister, 2001). Although many of the British sites that have provided evidence for this more complex record are in fluvial or fluvio-estuarine contexts, they are generally isolated one from another in separate systems and represent only very short windows of time as opposed to preserving more complete interglacial sequences. Examples, giving a flavour for the wide distribution of these localities, are Sugworth, Oxfordshire, in the Upper Thames (Shotton et al., 1980), Little Oakley, Essex, in the pre-diversion Thames-Medway (Bridgland et al., 1990), and West Runton, Norfolk, in an early river flowing north, perhaps to an offshore 'Ancaster River' (Rose et al., 2001).

Although it is to be anticipated that certain species may have a longer chronological range on the continent than in Britain, for example Ursus spelaeus, which disappears from Britain after MIS 11 but is present on the European mainland until the last cold stage (Weichselian), panEuropean comparisons have shown that the key biostratigraphical indicators that underpin the British mammalian scheme can aid correlation more widely, Thus, for instance, mammalian assemblages from the Ilm terrace traverine sequence at Weimar-Ehringsdorf, central Germany (Fig. 3), and from the later part of the Tourville Formation in the Seine valley of western France, bear close comparison to the two MIS 7 MAZs defined in the Lower Thames at Aveley (Schreve and Bridgland, 2001; Bridgland et al., 2004; Table 2). All three localities have yielded a diagnostic late form of Mammuthus trogontherii. In addition, distinctive Middle Pleistocene malacofaunas are well established in central Europe, notably the late Middle Pleistocene Helicigona banatica faunas from travertines in Thuringia (e.g. Thieme and Maier, 1995; Mania, 1995).

Molluscs have provided the raw material for the successful use of amino acid analysis as a geochronological method, first by determination of a leucine/isoleucine ratio from whole shells of particular species (Miller et al., 1979; Bowen et al., 1989, 1995) and later, in work that is still progressing, separating out the intra-crystalline amino acids and using several individual ones for age estimation (Penkman et al., 2007, this volume). The Thames and Avon

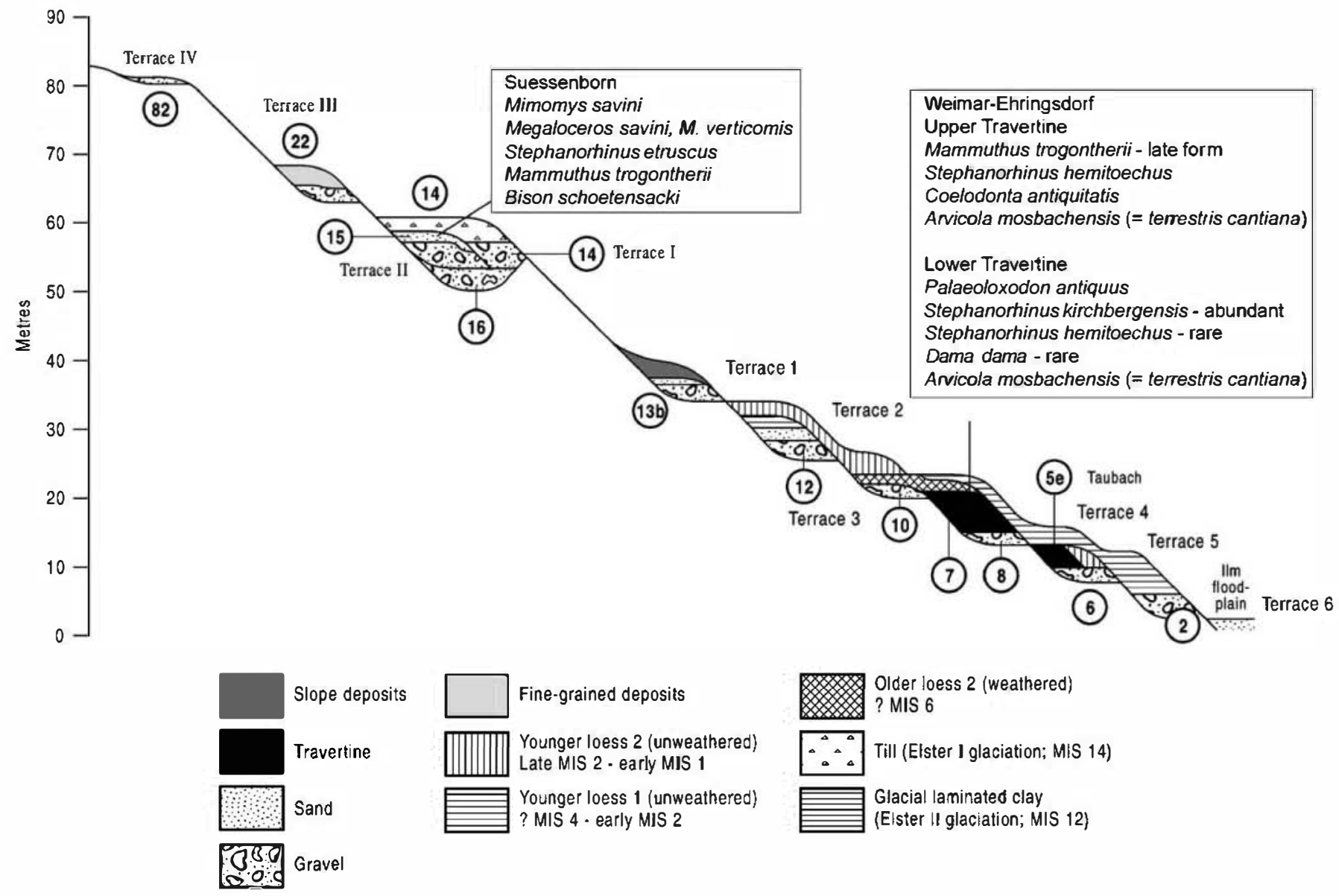

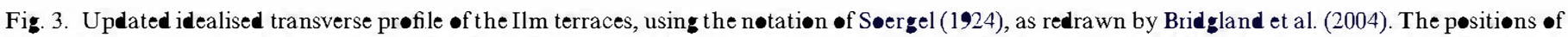

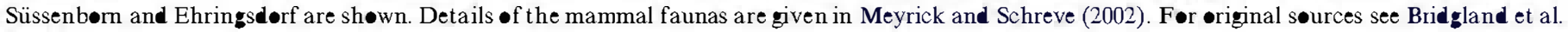
(2004). 
Table 2

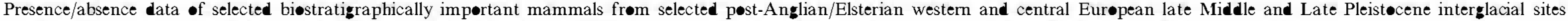

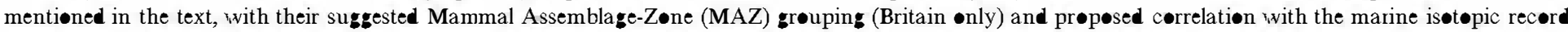

\begin{tabular}{|c|c|c|c|c|c|c|c|c|c|c|c|c|c|c|c|c|}
\hline \multirow[t]{4}{*}{ Taxon } & \multicolumn{16}{|c|}{ Suggested correlation with $\mathrm{MI}$ record } \\
\hline & \multicolumn{5}{|l|}{11} & \multicolumn{2}{|l|}{9} & \multicolumn{3}{|l|}{$7 \mathrm{e} / 7 \mathrm{c}$} & \multirow[t]{2}{*}{7} & \multicolumn{3}{|l|}{$7 \mathrm{a} ?$} & \multicolumn{2}{|l|}{$5 e$} \\
\hline & \multicolumn{15}{|l|}{ Site/MAZ } & \\
\hline & $\begin{array}{l}\text { Swanscombe } \\
\text { MAZ }^{(1)}\end{array}$ & $\begin{array}{l}\text { Račinèves } \\
\text { (2) }\end{array}$ & (3) & $\begin{array}{l}\text { Bilzingsleben } \\
\text { II }{ }^{(4)}\end{array}$ & $\begin{array}{l}\mathrm{La} \\
\text { Celle }\end{array}$ & $\begin{array}{l}\text { Purfleet } \\
\text { MAZ (פ) }\end{array}$ & $\begin{array}{l}\text { Cléon } \\
(\boldsymbol{*})\end{array}$ & $\begin{array}{l}\text { Ponds Fam } \\
\text { MAZ }\end{array}$ & $\begin{array}{l}\text { Ehringsdorf } \\
\text { Lr Trav }^{(4)}\end{array}$ & $\begin{array}{l}\text { Biache- St- } \\
\text { Vaast }{ }^{(7)}\end{array}$ & $\underset{\text { (7) }}{\text { Montières }}$ & $\begin{array}{l}\text { s Sandy Lane } \\
\text { MAZ (ร) }\end{array}$ & $\begin{array}{l}\text { Ehringsdorf } \\
\text { Up Trav (4) }\end{array}$ & $\begin{array}{l}\text { Tourville-1a- } \\
\text { Rivière }^{(7)}\end{array}$ & $\begin{array}{l}\text { Joint Mitnor } \\
\text { Cave MAZ }{ }^{(8)}\end{array}$ & $\begin{array}{l}\text { Trafalgar } \\
\text { Square }\end{array}$ \\
\hline Talpa minor & $\mathrm{X}$ & & & & & & & & & & & & & & & \\
\hline Trøgontherium cuvieri & $X$ & & $\mathrm{X}$ & $\mathrm{x}$ & & & & & & & & & & & & \\
\hline Ursus spelaeus & $\mathrm{X}$ & $\mathrm{X}$ & & $\mathrm{X}$ & & & & & $\mathrm{X}$ & & & & $\mathrm{X}$ & & & \\
\hline $\begin{array}{l}\text { Dama dama } \\
\text { clactoniana }\end{array}$ & $\mathrm{x}$ & & & $\mathrm{x}$ & & & & & & & & & & & & \\
\hline Oryctolagus cuniculus & $X$ & & & & & & & & & & & & & & & \\
\hline $\begin{array}{l}\text { Microtus (Terricola) } \\
\text { subterraneus }\end{array}$ & $\mathrm{X}$ & $\mathrm{X}$ & & $\mathrm{X}$ & & & & & $\mathrm{X}$ & & & & & & & \\
\hline $\begin{array}{l}\text { Arvicola } t \text {. cantiana } \\
\text { (= mosbachensis) }\end{array}$ & $\mathrm{X}$ & $X$ & $X$ & $X$ & & & & $X$ & $\mathrm{X}$ & & & & & & & \\
\hline Macaca sylvanus & $\mathrm{X}$ & & & $\mathrm{X}$ & $\mathrm{x}$ & $\mathrm{X}$ & & & & & & & & & & \\
\hline $\begin{array}{l}\text { Stephanorhinus } \\
\text { kirchbergensis }\end{array}$ & $\mathrm{X}$ & $x$ & & $x$ & & $\mathrm{X}$ & & & $x$ & $\mathrm{X}$ & $\mathrm{X}$ & $\mathrm{X}$ & & & & \\
\hline Equus ferus & $\mathrm{X}$ & & & $X$ & $X$ & $X$ & $X$ & $X$ & $\mathrm{X}$ & $\mathrm{x}$ & $\mathrm{X}$ & $\mathrm{x}$ & $\mathrm{X}$ & $\mathrm{x}$ & & \\
\hline $\begin{array}{l}\text { Stephanorhinus } \\
\text { hemitoechus }\end{array}$ & $X$ & $x$ & & $\mathrm{X}$ & & $\mathrm{X}$ & & & & $\mathrm{X}$ & & $\mathrm{X}$ & $x$ & & $x$ & $x$ \\
\hline Homo sp. & $\mathrm{x}$ & & & $\mathrm{x}$ & & $\mathrm{X}$ & $\mathrm{x}$ & $\mathrm{x}$ & $\mathrm{x}$ & $\mathrm{x}$ & & $\mathrm{x}$ & $\mathrm{x}$ & $\mathrm{x}$ & & \\
\hline Ursus arctos & & & & & & $X$ & $\mathrm{X}$ & & $\mathrm{X}$ & $\mathrm{X}$ & $\mathrm{X}$ & $\mathrm{X}$ & $X$ & & $\mathrm{X}$ & \\
\hline Dama dama dama & & & & & & $X$ & & & $x$ & & & & & & $X$ & $\mathrm{x}$ \\
\hline Crocuta crocuta & & & & & & $\mathrm{X}$ & & & $\mathrm{X}$ & & & $\mathrm{X}$ & & & $\mathrm{X}$ & $\mathrm{X}$ \\
\hline $\begin{array}{l}\text { Mammuthus } \\
\text { trogontherii (late form) }\end{array}$ & & & & & & & & & & & & $X$ & $X$ & $X$ & & \\
\hline $\begin{array}{l}\text { Coelodonta } \\
\text { antiquitatis }\end{array}$ & & & & & & & & & & & & $X$ & $X$ & $X$ & & \\
\hline $\begin{array}{l}\text { Arvicola terrestris } \\
\text { terrestris }\end{array}$ & & & & & & & & & & & & & & & $X$ & \\
\hline $\begin{array}{l}\text { Hippopotamus } \\
\text { amphibitus }\end{array}$ & & & & & & & & & & & & & & & $X$ & $X$ \\
\hline $\begin{array}{l}\text { Hippopotamus } \\
\text { incognitus }\end{array}$ & & & & & $X$ & & & & & & $X$ & & & & & \\
\hline
\end{tabular}

$\mathrm{X}=$ confirmed presence; ? = tentative attribution

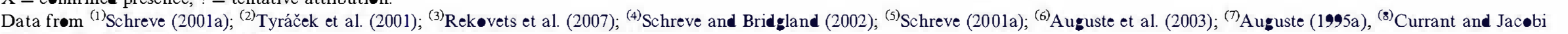
(2001). All •ther lata, this paper. 
terraces have formed important relative frameworks for these studies (Maddy et al., 1991; Bowen et al., 1989, 1995; Penkman et al., this volume).

\subsection{France}

In France, as in Britain, molluscan biostratigraphy has previously formed the basis for comparison with amino acid dating (Bates, 1993; Chaussé et al., 2000; LimondinLozouet 2001). The Retinella (Lyrodiscus) assemblage, generally recorded from tufas, is, as noted above, considered to represent part of MIS 11. As well as the aforementioned exotic $\boldsymbol{R}$. (L.) elephantium, this faunal grouping contains several extinct gastropods like Zonitoides sepultus, Aegopinella bourdieri, Aegopis acieformis, and species occurring well beyond their modern range such as Macrogastra ventricosa, Platyla similis, $\boldsymbol{P}$. polita, Ruthenica filograna, Neniatlanta pauli, Hygromia limbata and Ena montana. Although not directly representative of fluvial environments, the 'Lyrodiscus fauna' is an important marker within the Seine and Somme terrace sequences, occurring in tufas at St-Pierre-les-Elbeuf and Vernon in the Seine valley and at Arrest and St. Acheul in the Somme valley (Rousseau et al., 1992; Antoine and LimondinLozouet, 2004; Limondin-Lozouet and Antoine, 2006). The presence of tufa at St. Acheul, type locality of the Acheulean Palaeolithic industry, is an important discovery made during the course of IGCP 449 (Antoine and Limondin-Lozouet, 2004). The recognition of this distinctive assemblage within a well-dated fluvial sequence provides an important link to British localities at Hitchin (Kerney, 1959) and Beeches Pit, West Stow (Preece et al., 2006, 2007), both yielding tufas now interpreted as Hoxnian (MIS 11) but occurring outside major fluvial systems.

During the course of IGCP 449 a new research group called SITEP was initiated in Northern France. It is focused on the study of Pleistocene interglacial tufa deposits from MIS 11 to MIS 5 with the aim of characterizing each temperate period using a multi-proxy approach and appropriate means of dating. Early results have been obtained at two sites, La Celle in the Seine valley and Caours in the Somme valley, respectively attributed to MIS 11 and MIS 5 by radiometric measurements (Antoine et al., this volume). Not only did tufa accumulation prove to be several metres thick at both localities but both sequences were also found to contain evidence for human settlement, in the form of flint artefacts and modified mammalian remains. Molluscs, which are abundant throughout these calcareous formations, allow the reconstruction of landscape evolution in relation to climatic change. The successions begin with wet open-ground assemblages corresponding to pioneer biotopes during early interglacial times. Development of the forest environment is then emphasised by the appearance and spread of shade-loving taxa, allowing at their maximum the identification of the climatic optimum phase. The last stage is characterized by a return to open-ground molluscs, indicating drier biotopes and probably a decline of climatic conditions. The molluscan data from both La Celle and Caours can be characterized by a set of species extinct or beyond their modern range. At La Celle the 'Lyrodiscus fauna' is clearly identified and occurs within the optimum interglacial phase that also includes the Acheulean industry (Limondin-Lozouet et al., 2006). The characterization, at high resolution, of faunal succession within the MIS 11 interglacial offers strong future possibilities of correlation between the Seine and Thames sequences (see Schreve $2001 \mathrm{~b}$ for details of British MIS 11 mammalian faunal turnover). The importance of Caours as a site indicating human occupation of the Somme valley in the Last Interglacial is discussed elsewhere in this volume (Mishra et al., this volume).

In Northern France many fluvial sequences representative of temperate climatic conditions have yielded assemblages of large mammals. The oldest such evidence was recovered at Saint-Prest (Normandy) in sandy deposits of a very old terrace of the Eure river. The fauna, recently revised by C. Guérin et al. (2003), comprises Mammuthus meridionalis depereti, Stephanorhinus etruscus 'brachycephalus', Equus stenonis, Alces carnutorum, Megaloceros verticornis, Cervus cf. elaphus, aff. Dama sp., Bison schoetensacki, Hippøpotamus major, Trøgontherium cuvieri boisvilletti and Pachycrocuta brevirestris. This fauna, attributed to the Bavelian and considered to correlate with MIS 23 to 20, is thus one of the oldest fluvial mammalian assemblages in NW Europe. The assemblage bears strong similarities to that from Untermassfeld (central Germany), where fluviatile sands of the River Werra have been dated by geological, palaeomagnetic and biostratigraphical evidence to approximately $1.07 \mathrm{Ma}$ (MIS 31, immediately above the onset of the Jaramillo polarity subzone) (Kahlke, 2001).

Amongst the mammalian assemblage from the Carpentier quarry at Abbeville (Somme valley), the fauna from the lower part of the white marl is the most interesting from a biostratigraphical point of view. The taxa include Mammuthus meridionalis, Palaeoloxedon antiquus, Stephanorhinus etruscus 'brachycephalus', Hipp॰p॰tamus inc॰gnitus, Sus scrofa mosbachensis, a stenonid horse, Equus mosbachensis, Homotherium latidens, Megaloceros verticornis, Bison cf. priscus and Bes primigenius (Auguste, 1995a, 1995b). This mammalian association is of early Middle Pleistocene age, although there are notable differences with the type Cromerian fauna from West Runton defined by Stuart (1975, 1981). In particular, the presence of hippopotamus suggests a period of climatic conditions warmer than at present. An episode with relatively elevated temperatures has been recognised within the Cormerian Complex on the east coast of Britain, in fluvio-estuarine sediments of MIS 17 or 15 age at Pakefield (Parfitt et al., 2005), but West Runton itself has yielded no evidence of temperatures any warmer than at present (Stuart and Lister, 2001). The first appearance of $H$. incognitus in Northern France is 
noteworthy, since the species subsequently appeared regularly during temperate phases in the area.

Two sites have yielded important information on the evolution and migration of large mammals after MIS 12 . The first is Cagny-la-Garenne in the Somme valley, where fluvial levels $\mathrm{I}$ and $\mathrm{H}$ yielded several important taxa including Bos primigenius, Equus sp., Canis lupus mosbachensis and Cervus cf. elaphus. The horse is similar to caballine equids described by Eisenmann (1991) from British sites such as Hoxne, Clacton and Swanscombe, all three attributed to the Hoxnian (MIS 11) interglacial. The second site is at La Celle (see above, Table 2), also attributed to MIS 11, where remains of Cervus elaphus, Equus sp. (again similar to the Hoxnian caballine horse), Macaca sylvanus and $H$. incegnitus (the first record of this species from this interglacial) were recovered from the tufa sequence during a survey carried out in 2003. In Northern France, $H$. incegnitus appears again as part of the fauna of the MIS 7 interglacial at Montières (Boutmy-Muchembled quarry), in fluvial deposits of the Somme river (Auguste, 1995a). Hippopotamus is not thought to have reached Britain during either the MIS 11 or MIS 7 interglacials (Schreve, 2001a), despite its apparent presence on the adjacent continent during both episodes. Conversely, hippopotamus is absent from Last Interglacial deposits at Caours, in a tributary of the River Somme, despite being very common in British assemblages from the Eemian/ Ipswichian (Table 1) and also present in the German Rhine at this time (Kolfschoten, 2000).

The interglacial corresponding with MIS 9 has also been recognised at several sites in Northern France. At Cléon, in the Seine valley, it is characterized by the appearance of Stephan॰rhinus hemitoechus (Auguste et al., 2003; Table 2). The fauna preserved within the fluvial levels here includes Cervus elaphus, Bos primigenius, $S$. hemitoechus, Equus sp. and Palaeoloxodon antiquus. It is correlated with the fauna of Tourville-la-Rivière (lower part of the Tourville Formation) and allocated to the Domnitz interglacial, attributed to MIS 9.

Moving into the MIS 7 interglacial, sites with mammalian faunas become more numerous and allow the tracking of migrations on a large scale. The site of Biache-SaintVaast (Pas-de-Calais) offers a very detailed biostratigraphical record thanks to the preservation of large numbers of bones ( $>20000$ anatomically and specifically identified remains) from 20 species within a well understood chronostratigraphical sequence (Tuffreau and Sommé 1988; Auguste, 1995a). Many large mammals were recovered from the fluvial levels (Auguste, 1995a): Canis lupus cf. mediterraneus, Vulpes vulpes, Felis silvestris, Panthera spelaca, Ursus arctos, Ursus deningeri cf. hercynicus, A॰nyx antiqua, cf. Martes martes, Sus scrofa scrofa, Cervus elaphus elaphus, Megaloceros giganteus giganteus, Capreolus capreolus capreolus, Bos primigenius trochoceros, Equus cf. taubachensis, Equus hydruntinus, Stephanorhinus hemitoechus, Dicerorhinus mercki ( = Stephan॰rhius kirchbergensis), Palaeoloxodon antiquus and Castor fiber. The detailed and exhaustive study of this material has underlined the complexity of MIS 7, with at least two episodes of temperate faunas during this period, the first at the beginning of the stage around 250000 years BP (type fauna: Biache) and the second at the end of the stage around 200000 years ago (type fauna: Tourville-la-Rivière) (Auguste, 1995a; Auguste et al., 2003). The presence of two discrete mammalian faunal assemblages within MIS 7 directly parallels the British record (Schreve, 2001a, b), with the older of the two assemblages attributed to MIS 7e or 7c and the younger attributed to MIS 7a (Candy and Schreve, 2007) (Table 2). It has yet to be determined whether amino-acid racemisation can detect this level of resolution (see Penkman et al. this volume) but samples of B. tentaculata opercula are currently being processed with this aim.

Deposits of the Last Interglacial (MIS 5e) are relatively rare in continental Western European fluvial sequences, so the newly excavated site of Caours (Somme Valley) is of particular importance. Several levels of human settlements with a Middle Palaeolithic industry and a very characteristic mammalian assemblage were observed in this tufa sequence. The identified taxa comprise Bes primigenius, Cervus elaphus, Dama cf. clactoniana, Capreolus capreolus, Sus scrøfa, cf. Aønyx antiqua, cf. Palacoloxødon antiquus, Stephanorhinus sp. and Canis lupus. The mammalian fauna is dominated by forest species typical of temperate periods and reinforces the climatic interpretation deduced from the molluscan communities. An Eemian age also conforms to the position of the site within the Somme terrace staircase and is upheld by ESR dating (Antoine et al., 2006, this volume; Table 2). In summary, the multiproxy evidence derived from tufa deposits now makes an important contribution to understanding of the northern French river terrace sequences, given that they combine rich molluscan and mammalian faunas with the means for geochronological measurements. The recent discovery of many new tufa sites has substantially assisted in this aim and happily the famous tufa at St-Pierre-les-Elbeuf, thought to have been completely quarried away, was rediscovered towards the end of the IGCP 449 period, allowing new investigation of this important Seine deposit.

\section{Extending eastwards from central Enrope}

As part of the IGCP 449 Inaugural Meeting (Prague, April 2001), a field excursion was led to the Czech site at Račiněves, which lies within the terrace sequence of the River Vltava ( = Elbe). Previous interpretations of this site had recognised a supposed Holsteinian soil near the base of a loess sequence above the fluvial beds and from this had been proposed a late Cromerian Complex age for the Račiněves interglacial deposits, with their fauna and artefacts (Tyráček et al., 2001). With attention drawn to this site by the IGCP visit, consideration of the biostratigraphical implications of the mammalian assemblage led Tyráček et al. (2004) to reassign this interglacial deposit to 
the Holsteinian (MIS 11). The Račiněves assemblage has a number of taxa in common with the Swanscombe MAZ, notably the rhinoceroses Stephanorhinus kirchbergensis and $S$. hemitoechus and a large fallow deer (Dama dama clactoniana). Arvicola terrestris cantiana ( $=A$. mosbachensis) teeth from Račiněves have a characteristic Holsteinian morphology (Tyráček et al., 2001, 2004). The molluscan fauna comprises 22 taxa, including the woodland species Drobacia banatica and Aegopis verticillus, which, with Helicedonta •bveluta, Ena montana, Cochlodina laminata and Discus ruderatus, point to fully interglacial conditions. The absence of Helicigon capeki and Granaria frumentum, considered diagnostic of Cromerian Complex interglacials in the Czech Republic (cf. Záruba et al., 1977), supports the view that the Račiněves deposits date from MIS 11 (Table 2). This is the principal biostratigraphical site within the Vltava sequence and as such is an important stratigraphical marker (Tyráček et al., 2004). Elsewhere in this part of Europe fluvial mammalian faunas are relatively sparse and loess palaeosol stratigraphy is the more traditional means for erecting age models for terrace sequences, since the pioneering work of Kukla over 30 years ago (Kukla, 1975, 1978). Nonetheless, the data from Račiněves can provide an important link with another area where biostratigraphical evidence is prolific, the region to the north of the Black Sea and Caspian basins.

\subsection{Evidence from the Eastern European Plain}

Amongst the most impressive Late Cenozoic fluvial records are those left by the south-flowing rivers of the East European Platform, the Dniester, Dnieper, Don and Volga (Matoshko et al., 2002, 2004). Affected in their upper reaches by the major Quaternary glaciations, the Black Sea rivers have been periodically inundated in their lower reaches during marine highstands, a record complicated by the similarly driven separation and reconnection of the Black Sea and Mediterranean. The nature of these sedimentary records varies between an unbroken terrace staircase, in the case of the Dniester (Fig. 4), and mixes of stacked sediments and terrace formation, in the other three rivers, differences that can be related to crustal type (Westaway et al., 2003, Bridgland and Westaway, 2007). Faunal evidence is available from the sequences of all four rivers and has proved key to unravelling their age and evolution, with the Dniester regarded as the principal stratotype, although the Upper Pleistocene and Lower Pleistocene deposits of the Upper Don have yielded important small-mammal faunas (Matoshko et al., 2004).

Various fossil types are found in these fluvial sequences, including spores, pollen, plant macrofossils and ostracods, but, as in NW and Central Europe, vertebrate and molluscan palaeontology provide the principal biostratigraphical foundation (Matoshko et al., 2004). Molluscs have been used both for correlation and to establish fluvial marine interdigitation in the lowermost reaches of the rivers. The freshwater molluscan record was established by Tchepalyga (1967), using a combination of evolutionary change and migrations in response to climatic oscillations. Mammalian biostratigraphy has, however, been the most important tool for relative dating, with reference to defined mammal faunal complexes of the Pliocene Quaternary, based on evolutionary changes and extinctions (Gromov, 1948; Vangeingeim, 1982; Matoshko et al., 2004).

The Dniester has both the most impressive terrace staircase and the most complete biostratigraphical record of the four rivers under consideration (Matoshko et al., 2004). There are important small mammal assemblages from the Upper Don of Lower Pleistocene and Upper Pleistocene and several Lower and Middle Pleistocene suites of the Lower and Middle Dnieper also include fossiliferous deposits. However, information is lacking from many others; nevertheless, they represent the principal means of correlation between the four sequences (see below), as was documented in some detail by Matoshko et al. (2004), who also provide bibliographical details of the primary literature sources.

The biostratigraphical record from the Dniester commences with isolated discoveries of a mammal fauna containing Hipparion in the Late Miocene Balta Series, which pre-dates terrace incision (Fig. 4). Overlying these deposits, and also pre-dating the incision, is the latest Miocene/earliest Pliocene Stolnichen Series, presumed to represent the early part of the Moldova fauna (Fig. 4), which has yielded "Dicerorhinus" aff. megarhinus, Antilope sp., Hipparion sp., Gazella cf. borbonica, G. deperdita and Homotherium cf. crenatidens. The mollusc Plicatibaphia cf. wetzleri is also highly characteristic of this series. Dating of these deposits is complicated, since $G$. deperdita is known to have originated in SE or central Europe by $7.9 \mathrm{Ma}$ during Neogene Mammal Zone (MN) 12 and to have disappeared by around $5 \mathrm{Ma}$ (end of $\mathrm{MN} 13$ ) at the end of the Miocene (Made et al. 2006) but "D." megarhinus is not replaced until the beginning of the late Pliocene (Zone MN 15, 4.2 3.4 Ma) by its descendant "D." jeanvireti (Heissig, 1996). The first terrace suite to be formed after the initiation of incision is the Kuchurgan Suite, which contains Zygolophodon borsoni, Hipparion gracile ( = Hippotherium primigenium), "D." megarhinus, Promimomys moldavicus and Pliomys kowalskii, representing the Moldova faunal complex of the early Pliocene (Fig. 4). The last two species appear in eastern Europe during the late Ruscinian of the European Mammal Faunal seccession (Zone MN 15) (Pevzner et al. 2001). Molluscs such as Plicatibaphia flabellatiformis, Psiluni•

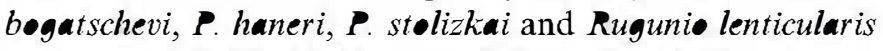
are common in the Kuchurgan Suite and in the subsequent Runkashiv Suite (Fig. 4). The latter suite was correlated by Matoshko et al. (2004) with the Sokol Suite of the Kinel' series, defined in the Kama tributary of the Middle Volga. It contains a characteristic molluscan assemblage, with Viviparus dresseli, $V$. mangikiani, $V$. achatinoides glogovensis, Valvata vanciana, V. piscinalis, Borysthenia naticina, Bithynia spoliata, B. vuk॰tin॰vici, Lithøglyphus rumanus, 


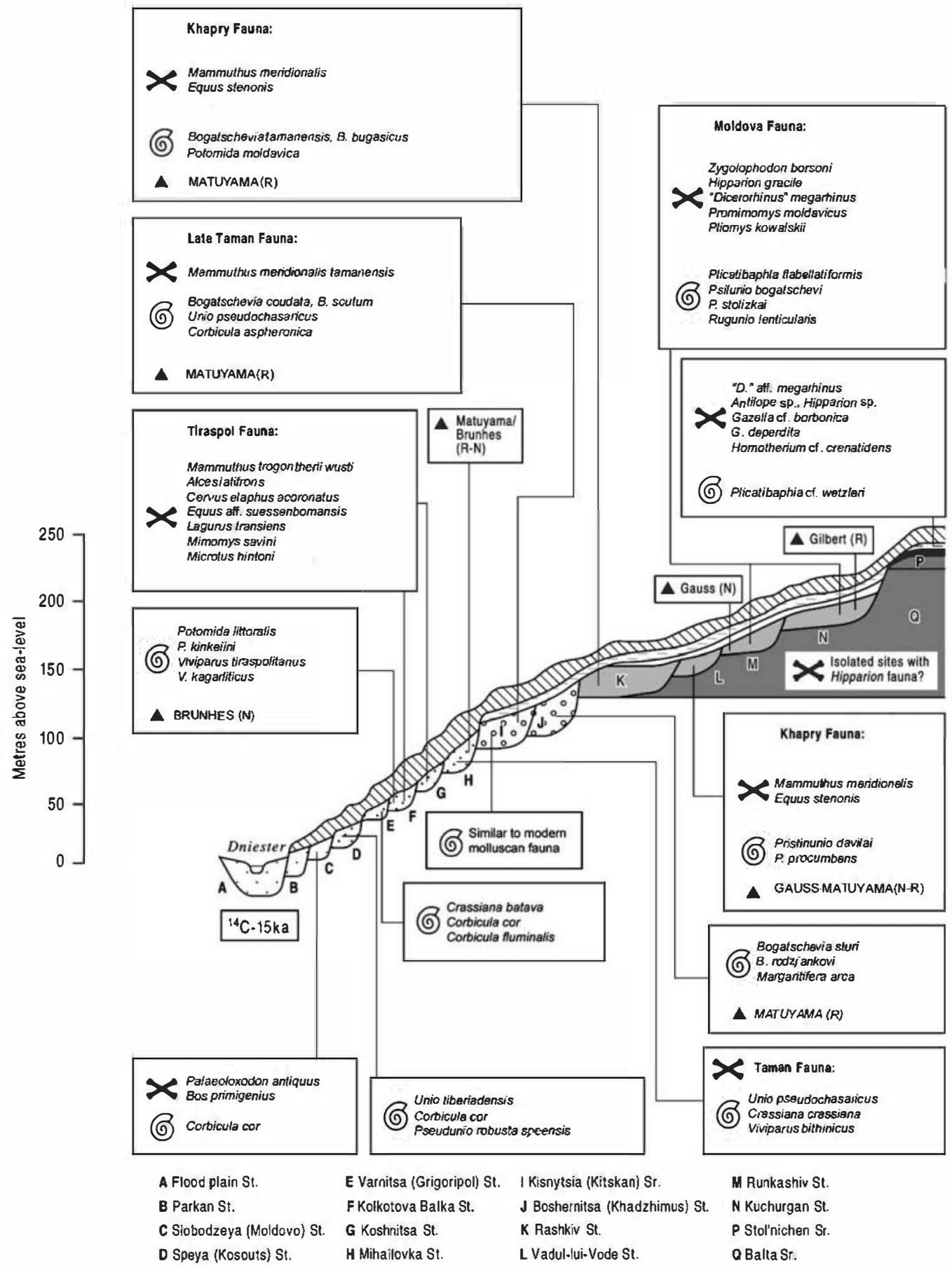

Fig. 4. Generalised transverse prøfile thrøu the Middle-Løwer Dniester sediments (see Fig. 3 captiøn for søurces), shøwing biøstratigraphic and

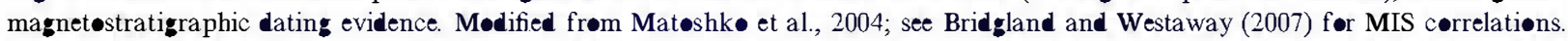

Uni॰ ex gr. rumanus, Potomida sibinensis and Psiluni॰ serratoradiatus. The next terrace is formed by the Vadullui-Vode Suite, which has yielded the molluscs Pristinunidavala $i$ and $\boldsymbol{P}$. procumbens, along with mammals such as a primitive subspecies of Mammuthus meridionalis (sometimes referred to as "Archidiskodon" gromovi) (Lister and Sher, 2001) and Equus stenonis. This Dniester suite is correlated with the Uryv Series of the Upper Don, on the basis of small mammals, and with the Khapry Suite of the Lower Don, from which the Khapry mammal complex is defined (Matoshko et al., 2004). The Khapry Sands are magnetically reversed and are considered to lie within the earlier part of the Matuyama Chron just above the GaussMatuyama reversal at $2.5 \mathrm{Ma}$, whereas the mammalian fauna has been correlated with the Middle Villafranchian (Zone MN 17, ca 2.5 1.5 Ma). The final Pliocene terrace of the Dniester, formed by Rashkiv Suite (Fig. 4), also yields fauna representative of the Khapry mammal complex, including the molluscs Bogatschevia tamanensis, B. bugasicus and Potomida (Wentzienella) moldavica. 
The earliest Pleistocene terrace of the Dniester is formed by the Boshernitsa Suite (Fig. 4), in which is found the early Tamanian mammal complex, together with molluscs such as Bogatschevia sturi, B. Uni॰ sturi var. rodzjankøvi and Margaritifera arca. It is correlated with the middle suite of the Goryanka Series of the Upper Don, which is characterized by small mammals such as Mimomys ex. gr. pusillus, M. savini and Allophaiomys pliocaenicus of the same faunal complex (Holmovoi et al., 1985). The next Dniester terrace, formed by the Kisnytsia Series, contains molluscs such as Uni@ sturi var. caudata, Uni sturi var. scutum, Unio (Eølymnium) pseudochasaricus and Corbicula apsheronica, together with mammals of the late Tamanian complex (ca $1 \mathrm{Ma}$ ), such as Mammuthus meridionalis tamanensis. The last species is considered to represent and 'advanced' form showing enhanced variability towards Mammuthus trogontherii, although its broad morphological range suggests it is not a simple intermediate (Lister and Sher, 2001).

The Early Middle Pleistocene transition is best established in the Don, where the most advanced Early Pleistocene faunas occur, characterized by the Petropavlovka fauna, with Microtus (Pallasiinus) ex gr. oeconomus, the steppe lemmings Prolagurus pannonicus and Eølagurus argyrøpuloi and the vole Micrøtus hintoni (Krasnenkov and Agadjanian, 1975; Alexandrova, 1976; Markova, 1998). A comparable small mammal fauna occurs in the lower Dnieper near Karai Dubina (Markova, 1982). Palaeomagnetic studies have placed the beds with this fauna in the upper part of the Matuyama Chron (Velichko et al., 1983), corroborating a terminal Early Pleistocene age (Matoshko et al., 2004). Although it has been suggested that the Petropavlovka Suite marks a distinctive biostratigraphic substage (Alexandrova, 1976), or that it marks the start of the Tiraspolian biozone (Holmovoi et al., 1985; Rekovets, 1994), or the end of the earlier Tamanian biozone (Markova, 1998), Matoshko et al. (2002, 2004) have regarded it as transitional between the Tamanian and Tiraspolian biozones. An age within MIS 20 for Petropavlovka Suite has been proposed by Iossifova (2001).

The next Dniester terrace suite, the Mihailovska Suite, represents the earliest Middle Pleistocene (Tiraspolian), followed by the Koshnitsa and Kolkotov Suites forming the next two terraces, also of Middle Pleistocene age (Fig. 4). The Tiraspolian is characterised by the presence of Mammuthus trogontherii wusti, Alces latifrons, Cervus elaphus acoronatus, Equus aff. suessenbornensis, Lagurus transiens, Microtus hintoni and Mimomys savini. The molluscan assemblage in the Koshnitsa Suite is similar to that from the Holocene, whereas the later Kolkotov Suite has a subtropical malacofauna, with Potomida littoralis, $\boldsymbol{P}$. kinkelini, Viviparus tiraspolitanus and $V$. kagarliticus. There is a well-established biostratigraphical correlation between the Kolkotov Suite and the Nikopol Suite of the Lower Dnieper, the Muchkap Suite of the Upper Don and the Venedy Series of the Middle Volga (Matoshko et al., 2004).
The succeeding terrace, represented by the Varnitsa Suite (Fig. 4), falls biostratigraphically within the Singil mammal complex. This biozone is named after the Singil Suite of the Caspian basin, which represents a relatively minor transgression of the Caspian Sea (Matoshko et al., 2004), and marks the Mimomys Arvicola transition recognised throughout Europe (Turner, 1996; Matoshko et al., 2004). The Singil fauna is better known from the equivalent Kryvichi Series of the Dnieper and Volga; in the Middle Dnieper it is characterised by Arvicola chosaricus, Arvicola mosbachensis ( = terrestris cantiana), Eolagurus luteus, Micrøtus gregalis, Micrøtus arvalis, $M$. ॰econ॰mus, Cricetus praeglacialis and Lagurus lagurus. In the Upper Don the important Mimomys Arvicola transition seems to occur between the Muchkap and Tafino Suites (Iossifova, 1977; Turner, 1996). The lowest three terraces of rivers on the East European Platform (Speya, Siobodzeya and Parkan suites in the Dniester Fig. 4) are characterized by late Middle/Late Pleistocene mammalian species of the Upper Palaeolithic faunal complex, such as Coelodonta antiquitatis, Megaloceros giganteus ruffi, Cervus elaphus, Capreolus capreolus, Rangifer tarandus, Bison priscus and Mammuthus primigenius.

These four east European rivers have provided some of the most important data that has been contributed to IGCP 449 , both in terms of their biostratigraphy and more widely for correlation purposes (for their possible correlation with the marine oxygen isotope record see Figs. 4 6). Their contrasting records (Matoshko et al., 2002, 2004), with a terrace staircase in the Dniester, a complex sequence of nested, inset staircases in the Upper Don (Fig. 5) and laterally disposed sediment bodies of various ages within $\pm 50 \mathrm{~m}$ of the modern river level in the Middle Dnieper (Fig. 6), has been linked to crustal type and, being in a similar climatic zone to other European rivers, have helped to establish the importance of this criterion for understanding uplift (Bridgland and Westaway, 2007).

There are other important issues in correlating faunas between these eastern extremities of Europe and the core project area further west. In particular, evidence from the Black Sea area is critical with respect to the recent controversial case advanced in Britain for evidence of glaciation during MIS 16 (the Happisburgh Till), reputedly recorded in relation to the Bytham River sequence of East Anglia (Hamblin et al., 2000; Lee et al., 2004). This has been challenged by other stratigraphers and biostratigraphers, who have pointed to important differences in faunas occurring above and below the Happisburgh Till and those similarly disposed in relation to the long-established early Middle Pleistocene Don glaciation, also widely believed to date from MIS 16 (Pevzner et al., 2001). The Don Till is both underlain and overlain by sediments containing archaic water voles of the genus Mimomys, which have rooted molar teeth, whereas the Happisburgh Till overlies sediments with the later descendant form with continuously growing (unrooted) molars, belonging to the genus 


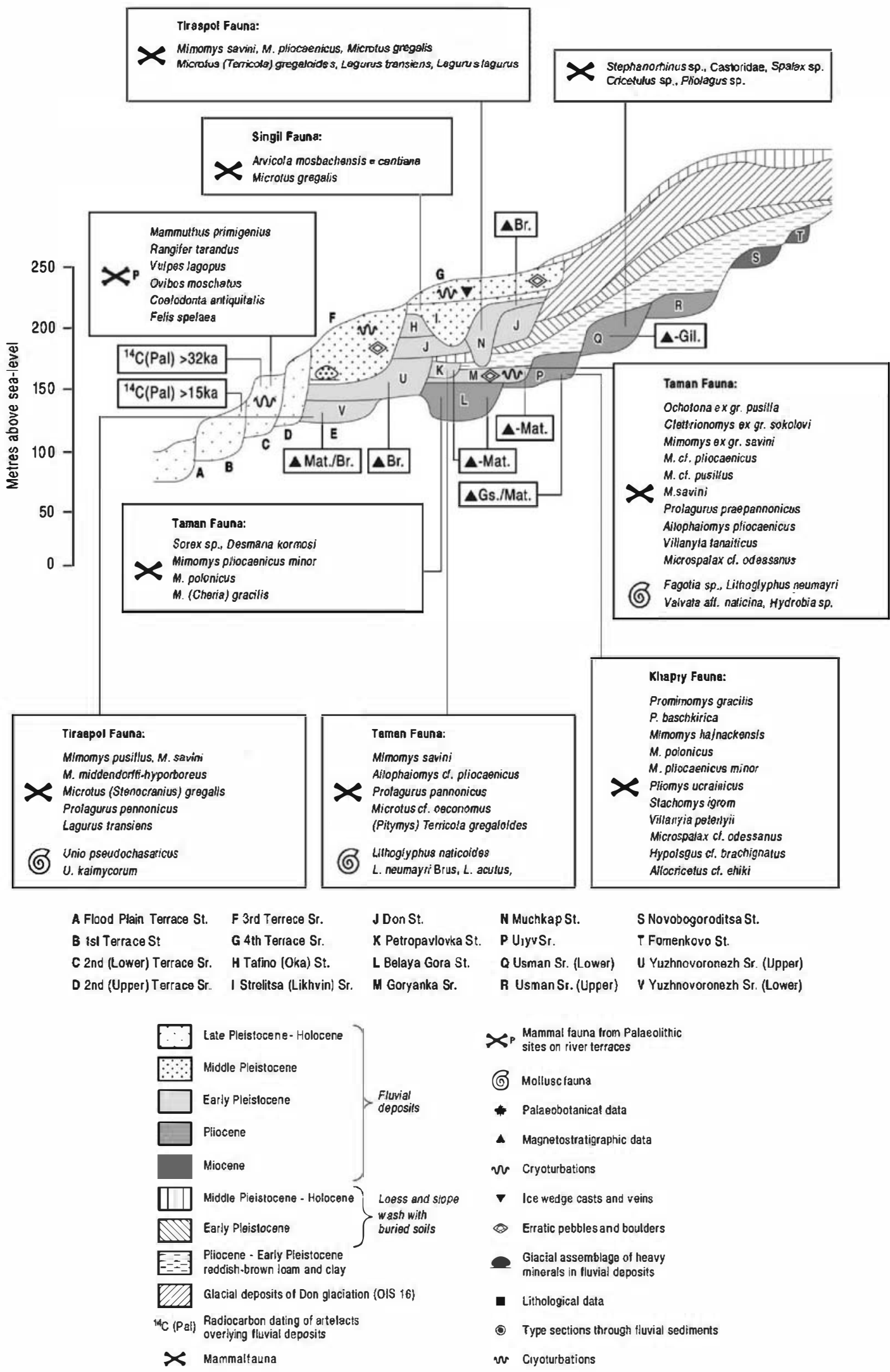

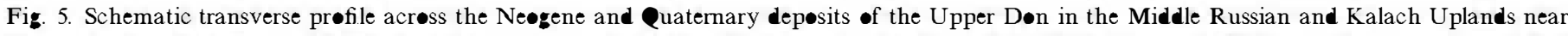

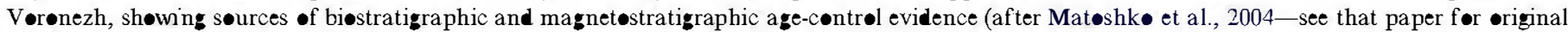

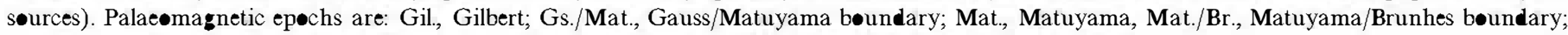

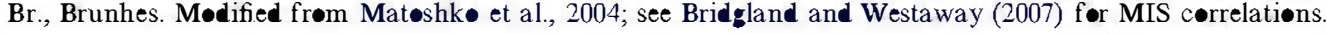



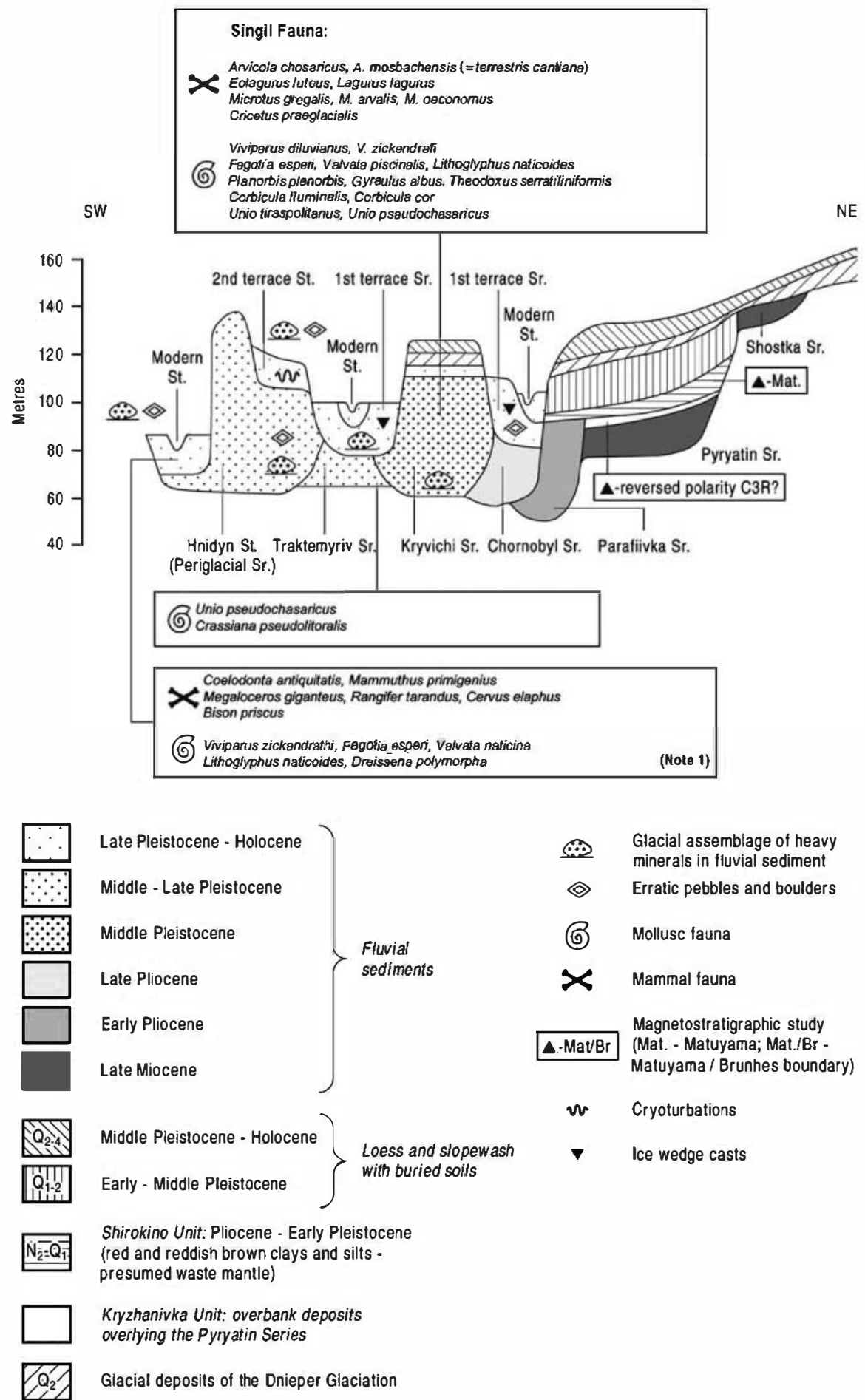

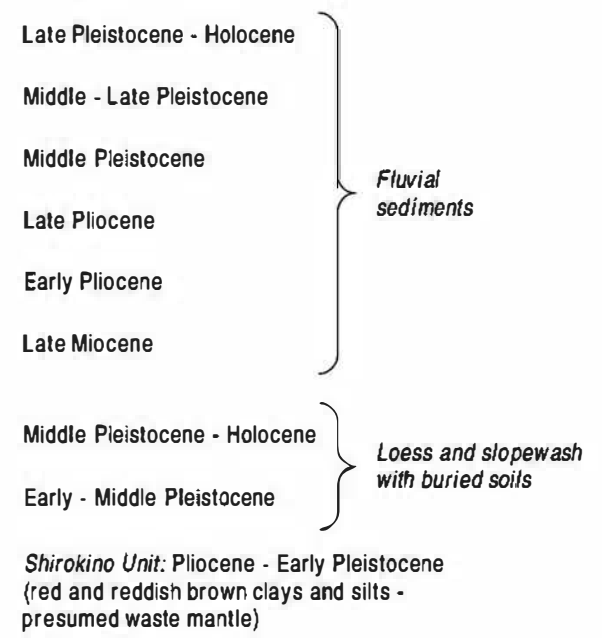

Glacial assemblage of heavy
minerals in fluvial sediment
Erratic pebbles and boulders

Kryzhanivka Unit: overbank deposits overlying the Pyryatin Series

Glacial deposits of the Dnieper Glaciation

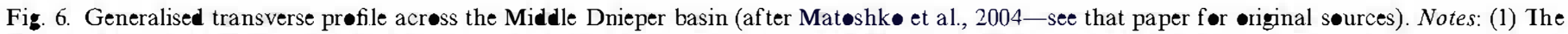
listed fauna frøm the Mødern Suite may include material rew

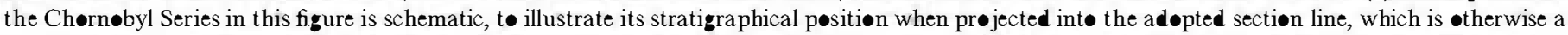

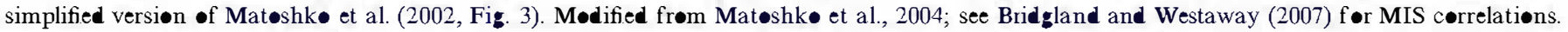

Arvicola. The transition from Mimomys to Arvicola has long been regarded as one of the most important biostratigraphical markers in the European Pleistocene. Since it is likely that this evolutionary advancement was perpetuated in the water vole population extremely rapidly (given the rapid reproduction and turnover rate in microtine rodents) and Britain was at that time permanently connected to the European mainland by a land bridge (thereby allowing free movement of terrestrial mammals), it is difficult to see how the Don and Happisburgh glaciations can be of the same age (Banham et al., 2001; Preece and Parfitt, 2007) unless there is 
a marked diachroneity in the evolutionary transition between Mimomys and Arvicola across Europe.

Correlation across Europe and with the marine oxygen isotope stratigraphy of the Dnieper glaciation (e.g. Matoshko, 1995), is equally controversial. In Central and Eastern European schemes, the Dnieper stage has generally been attributed to MIS 8 (e.g. Šibrava, 1986; Matoshko et al., 2004) but it is also generally correlated with the Saalian glaciation. In the Netherlands, the Saalian is equated with MIS 6 (Zagwijn, 1974; Turner, 2000), although in the type Saale River area in Germany an MIS 8 age might fit better with the biostratigraphical evidence, from the terrace sequences of Saale tributaries such as the Wipper and Ilm (Figs. 1 and 2) and the correlation of these with the semi-stacked sequence at Schöningen (Bridgland et al., 2004). According to Vasiliev (1980), outwash from the successive Dnieper, Moscow and Valdai glaciations feeds into terraces of the Volga, potentially recording ice sheets in MIS 8, 6 and 2, respectively (Matoshko et al., 2004).

A more recent contribution from this area by Rekovets et al. (2007) has documented data from a Middle Pleistocene site at Medzhybozh in the Third Terrace of the Yuzhny Bug, a smaller Ukrainian river flowing to the Black Sea between the Dniester and Dnieper courses. This site combines biostratigraphy with stratigraphical evidence, in which two superimposed alluvial cycles are indicated, the lower of which has yielded Palaeolithic artefacts (see Mishra et al., this volume). The best evidence both for distinguishing the two cycles and for estimating their age comes from biostratigraphy, in particular the evidence from the SDQ index of enamel differentiation in Arvicola (see Heinrich 1982, 1987 for details of methodology). Although challenges remain in directly comparing lineages from different regions, the broad trend across Europe is for SDQ indices to progressively decrease from the early Middle Pleistocene to the present (Kolfschoten, 1990; Maul et al., 1998; Maul and Markova, 2007). In the earlier cycle at Medzhybozh, Rekovets et al. (2007) calculated SDQ values of $\sim 116$, whereas in the younger cycle they have fallen to 107, leading them to favour an MIS 11 age for the former (Table 2).

\section{Comparison over wider areas}

Extension of the approach that has been used in the IGCP 449 core area to more distant regions is hampered by the unsurprising variation of faunal components, as different climatic and geographical provinces are encountered. Northward extension is largely precluded by the paucity of long-timescale records in areas inside the limits of the main Quaternary glaciations. To the south lie areas within the Mediterranean climatic zone, where preservation is frequently better but faunal turnover can of ten be less pronounced than in higher latitudes, leading to problems differentiating different climatic stages. Notable exceptions occur in the fluvial terraces of Italy, some parts of Iberia and the Levant (see below). Extension eastwards towards Asia runs parallel with the climatic zones and so might be expected to show similar patterns of faunal turnover to the west. This is largely borne out by the recognition of comparable faunal zones in Russia, albeit with different classification systems and with taxonomic uncertainties that require further consideration.

\subsection{Evidence from southern Eurøpe}

Fossiliferous fluvial deposits occur in many areas of southern Europe, complementing the data that come from cave sites and other environments in that area. In Spain, the oldest dated fluvial terrace corresponds to the $165 \mathrm{~m}$ level of the Pisuerga River (Duero basin) that includes the Tarriego de Cerrato fossil locality, with a mammal fauna belonging to the upper Miocene (Santisteban et al., 1997; Mediavilla, 2001). For the Quaternary, there an important Early Pleistocene fauna occurs in bed 3 at Fuente Nueva, in the upper part of the stacked fluvial/lacustrine sequence of the Guadix-Baza basin (Martínez-Navarro et al., 1997). Associated with reported early archaeological material are Mammuthus meridionalis, Stephanorhinus etruscus, Megaloceres solithacus, Megantereon whitei, Allophaiomys bourgondiae and Allophaiomys chalinei. Bed 3 is magnetically reversed (Matuyama Chron) and is thought to slightly predate the Jaramillo subchron $\sim 1.1 \mathrm{Ma}$ (Martínez-Navarro et al., 2005). The occurrence of $M$. meridionalis provides an indication of an Early Pleistocene age for high terraces of several Iberian rivers, notably the $8085 \mathrm{~m}$ terrace of the River Manzanares, a tributary of the Tagus (cf. Bridgland et al., 2006; Santisteban and Schulte, this volume) and at the sequence of sequence of Pinedo, where it appears at the $60 \mathrm{~m}$ terrace, in a lower position than the finding of Equus stenonis $(+75 \mathrm{~m})$, and where a paleomagnetic measurement places the beginning of the Bruhnes Chron at that terrace of the Tagus River (Aguirre, 1964).

Four fossil sites of Early Pleistocene age are located in the Spanish Southern Meseta (Guadiana and Jucar rivers). In the Guadiana River, Valverde-2 has yielded Equus cf. stenønis, Cervidae indet., Bovidae indet. and Elephantidae indet. (Alberdi et al., 1984), dated to 19 1.5 Ma (Mazo, 1999). Valverde-1 faunas are composed of Mammuthus meridionalis, Hippopotamus amphibius major, Equus caballus mosbachensis, Eucladoceros dicranios and Leptobos etruscus (Molina et al., 1974). The site of El Provencio, in the $1516 \mathrm{~m}$ terrace of the former Guadiana River, has yielded Mammuthus meridionalis and Bovidae indet. (Mazo et al., 1990) and it is correlated with the Fuensanta de Júcar site, on the $60 \mathrm{~m}$ terrace of the Júcar River and dated to ca $1 \mathrm{Ma}$, which contains Mammuthus meridionalis, Hipp॰ptamus major and Cervidae indet. (Mazo et al., 1990).

The Middle Pleistocene is substantially richer in terms of faunal preservation and abundance, especially the ubiquity of Palaedoxodon antiquus, which is characteristic of this period in Spain and elsewhere. The celebrated Torralba archaeological site can be placed between the 22 and $35 \mathrm{~m}$ 
terraces of the Masegar River (Ebro basin) and the $20-25 \mathrm{~m}$ and $30-35 \mathrm{~m}$ terraces of the Upper Henares River (Tagus basin). The fauna from this locality is typically late Middle Pleistocene and includes Crocidura sp., Microtus brecciensis, Arvicola aff. sapidus, Apodemus aff. sylvaticus, Oryctolagus sp., Canis lupus, Panthera sp., P. antiquus, Equus caballus torralbae, Stephanorhinus hemitoechus, Capreolus sp., Cervus elaphus, Dama cf. dama and Bos primigenius.

In the Duero basin, in the tributary Pisuerga River sequence are a number of important fossil localities. The $165 \mathrm{~m}$ terrace of this river includes the Tariego de Cerrato fossil locality, with a mammal fauna belonging to the upper Miocene (Santisteban et al., 1997; Mediavilla, 2001), whereas in the $1820 \mathrm{~m}$ and $3035 \mathrm{~m}$ terraces, $\boldsymbol{P}$. antiquus appears in association with Equus sp. and Bos sp. (Santonja and Pérez-González, 1984). On the Mediterranean side, $\boldsymbol{P}$. antiquus appears together with Equus cf. chosaricus, $S$. hemitoechus, Cervus sp., Crocidura sp., Oryctolagus cf. cuniculus, $A$. cf. sapidus, Eliomys quercinus, Micrøtus brecciensis-cabrerae, Allocricetus bursae and Apodemus sylvaticus at the $5060 \mathrm{~m}$ terrace of the Alfambra River, where a TL date provides an age of $137.9 \pm 10.07 \mathrm{ka}$ (Santonja et al., 2000).

The Tagus River is, however, substantially richer in fossil sites for this period, although there is relatively little faunal turnover between different climatic episodes. The $40 \mathrm{~m}$ terrace of this river near Toledo yields remains including Mammuthus trogontherii, Megaloceros savini, Equus caballus, Hippopotamus amphibius, Eliomys quercinus, $A$. bursae, $M$. brecciensis and $A$. cf. sylvaticus, while the $2530 \mathrm{~m}$ terrace at Pinedo presents Lepus cf. europaeus, Oryctolagus cuniculus, Equus sp., Cervus elaphus, Bos sp., Hipp potamus amphibius, Megaloceros savini and $\boldsymbol{P}$ antiquus (Aguirre, 1964). Upstream, the presence of $\boldsymbol{P}$. antiquus at the Aridos 1 and 2 sites (Santonja et al., 2001a) provides ages for the $4042 \mathrm{~m}$ terrace of another Tagus tributary, the Jarama River, while assemblages containing $\boldsymbol{P}$. antiquus and Megaloceres sp. in the $2530 \mathrm{~m}$ terrace of the Manzanares (Santonja et al., 2001b) allow the correlation of both terraces. The suggested ages are MIS 109 for the $4042 \mathrm{~m}$ terrace, MIS 1311 for the $2530 \mathrm{~m}$ terrace of the Manzanares and MIS 146 for the $30 \mathrm{~m}$ terrace (PérezGonzález, 1994; Sesé and Soto, 2000; Santonja and PérezGonzález, 2000, 2001).

A Late Pleistocene faunal assemblage in the Tagus basin has been identified at the Arroyo del Culebro (Santonja et al., 2001b), including Megaloceros cf. giganteus and Coelodonta antiquitatis.

With the above noteworthy exceptions, much of the rest of the Iberian Peninsula lacks faunal preservation in fluvial sediments, despite widespread limestone outcrops. A typical example of this is the Guadalquivir River in southern Spain, where a succession of 12 terraces has been mapped. Terraces 14 attributed to the Early Pleistocene, terraces 58 to the Middle Pleistocene, terraces 9 and 10 to the Late Pleistocene and terraces 11 and 12 to the Holocene (Díaz del Olmo and Vallespí, 1988). Although Palaeolithic artefacts are present throughout (Vallespí, 1988), disappointingly few faunal remains are preserved, with the exception of $\boldsymbol{P}$. antiquus and E. hydruntinus in terrace 8, associated with an Acheulean industry.

The biostratigraphical record of the Italian peninsula is much better known, in particular the archive from the Tiber River basin, which spans much of the Pleistocene. New mammalian assemblages of Late Pliocene latest Early Pleistocene age have been recovered from fluvio-lacustrine deposits of the Santa Maria di Ciciliano Formation at Colle Logato and at Colle Poggette near Montecastrilli. From the same area three fossiliferous localities have been previously studied: Torre Picchio, Villa Santo FaustinoColle Santa Andrea and Colle Santo Umano (Girotti et al. 2003; Sardella et al. 2003). An important Middle Pleistocene sequence is known from the Ponte Galeria Formation, in the Campagna Romana outside Rome. Here, the Brunhes Matuyama boundary is recorded with reversepolarised lagoonal clays characterised by Helicella (reversed polarity, MIS 22) overlain by normally polarised clays with Venerupis senescens (MIS 19). Micromammalian remains from the Helicella clays at Fontingnano are indicative of cold-climatic conditions and include Praedicrostonyx sp. and Prolagurus pannonicus (Sardella et al., 2003). A succession of named faunal units have subsequently been defined for the Early and early Middle Pleistocene (Galerian Mammal Age) and late Middle Late Pleistocene (Aurelian Mammal Age) (Gliozzi et al. 1997).

\subsection{Evidence from the Levant}

There are relatively few well-documented fossiliferous pre-Holocene fluvial sequences in the Levant. The Mesopotamian rivers Euphrates and Tigris have readily observable terrace sequences (e.g. Tyráček, 1987; Demir et al., this volume), but there are no records of faunal assemblages in currently accessible reaches in Turkey or Syria. Syria's second-largest river, the Orontes (Asi), also has a clear terrace record in its middle (Besançon and Sanlaville, 1993; Dodonov et al., 1993) and upper reaches (Bridgland et al., 2003b). The Upper Orontes terraces, although calcareously cemented, are devoid of fossils, but at $\sim 50 \mathrm{~m}$ above the river in the Middle Orontes, $100 \mathrm{~km} \mathrm{NW}$ of Hama, is a rich faunal and Palaeolithic site at Latamneh. This has produced a significant vertebrate fauna, providing the key pinning point for biostratigraphically constraining the ages of Orontes terraces (Bridgland et al., 2003b; Bridgland and Westaway, 2007; Mishra et al., this volume). The assemblage includes Mammuthus trogontherii, Stephanorhinus hemitoechus, Megaloceros verticornis and Equus cf. altidens (Guérin and Faure, 1988; Guérin et al., 1993). It thus combines a giant deer species that are unknown in Europe after the Elsterian with a rhinoceros that first appears in Europe immediately after that glaciation, in the Holsteinian. The likely correlation with the oceanic oxygen isotope sequence is therefore probably between MIS 13 and 11. 
The paucity of faunal remains in post-Holocene fluvial deposits in this region, despite widespread calcareous bedrock, is both a surprise and a disappointment. The fluvial sediments in limestone areas are widely calcreted, a phenomenon that is highly characteristic of semi-arid Mediterranean areas (Candy et al., 2004, 2005). The one significant Orontes faunal locality, at Latamneh (see above) is from an area where the gravels remain uncemented, raising the possibility that faunal remains are destroyed during, or in advance of, the formation of the calcite cement.

\section{Data from other regions}

Thus far this review has considered data that can be compared with those from the core NW/Central European area of IGCP 449. There has also been project activity on distant continents where faunas have minimal or no overlap with that in the core area. Nonetheless, palaeontological data from the fluvial sequences in such areas can be of value for environmental reconstruction and for establishing regional biostratigraphies. Brief details of some of the most important data, entirely mammalian, are given below.

\subsection{Sub-Saharan Africa}

Mammalian faunas are valuable for gauging the age of the important Plio-Pleistocene hominin fossils and archaeological assemblages from East Africa, such as in the Awash and Omo Valleys in Ethiopia (Jaeger and Wesselman, 1976; Read, 1997; Geraards et al., 2004). At the southern extremes of the African continent, in the Southern Hemisphere temperate climatic zone, the fluvial sequence of the Vaal-Orange River has been studied over a lengthy period and has yielded mammalian assemblages (Cooke, 1949; Helgren, 1977) that assist with age determination (Klein, 1983; Beaumont, 1999; see Mishra et al., this volume), although many of the fossiliferous sites are from non-fluvial contexts on the valley floor.

\subsection{South America}

Mammalian biostratigraphy has been applied to fluvial sediments in Uruguay, in a contribution to IGCP 449 and to the subgroup by Ubilla (2004). He described the fossiliferous beds of the Sopas Formation, which outcrop in northern Uruguay between the Uruguay and Negro rivers and have also yielded freshwater molluscs, plants and trace fossils as well as vertebrates. The mammalian assemblage includes highly exotic and extinct taxa such as the capybara Neochoerus aesepi, the glyptodont Neuryurus rudis, and Antifer ultra and Morenelaphus brachyceros, extinct species of deer (Fig. 7). The assemblage is correlated biostratigraphically with the Lujanian Stage (Late Pleistocene Early Holocene) of the Pampean region of Argentina. Minimum radiocarbon ages (43000 years BP and 45000 years BP: Ubilla and Perea, 1999) along with luminescence dates $(43.5 \pm 3.6$ and $58.3 \pm 7.4 \mathrm{ka}$ : Ubilla, 2004) provide corroboration of this interpretation.

The finds from the Sopas Formation have been placed in the context of a mammalian biostratigraphical scheme for the Pliocene to Recent in the Pampean region of Argentina proposed by Cione and Tonni (1999). This scheme provides a framework for regional correlation in South America including mammalian assemblage biozones. As shown in Fig. 7, it envisages three Pleistocene divisions, the Ensenadan, Bonaerian and Lujanian Stages, which are defined by the Tolypeutes pampaeus, Megatherium americanum and Equus (Amerhippus) neogeus biozones, respectively. According to Cione and Tonni (1999) and Nabel et al. (2000), the Ensenadan spans the Late Pliocene early Middle Pleistocene, whereas the Bonaerian represents the Middle Pleistocene and the Lujanian, with which the assemblage from the Sopas Formation is correlated, is Late Pleistocene Early Holocene. Differences in the fauna from the Sopas Formation in comparison with the typical Lujanian mammal fauna of the fluvial Guerrero Member of the Luján Formation in Buenos Aires province (Prado and Alberdi, 1999; Tonni et al., 1999) were interpreted as a consequence of both temporal differences and, potentially, of distinct biogeographical and climatic phases (Ubilla, 2004). The assemblage from Uruguay indicates warm and humid conditions, whereas that from the Guerrero Member points to a colder and more arid environment. The Sopas Formation has yielded mammals indicative of diverse habitats, however. Amongst the extant species are examples that inhabit fluvial and lacustrine environments with riparian forest, open woodland, savannah and grassland. For more detailed discussion of the well developed biostratigraphical arguments, see Ubilla (2004) and references therein.

\subsection{Australia}

Fossils from Quaternary fluvial deposits in Australia are of fairly minor significance in a field of study that has been dominated by attention to interactions between aeolian, lacustrine and riverine environments, questions of fluctuating and, indeed, progressively increasing aridity in relation to monsoonal precipitation and a extremely successful programme of TL dating of quartz sands, underpinning the story (Kershaw and Nanson, 1993; Nanson and Price, 1998). On this southern continent, many large animals (mainly mammals, which were smaller than 'megafauna' elsewhere, but including birds) became extinct in the Late Pleistocene. They included the giant wombats Diprotodon and Zygomaturus trilobus, the large kangaroos Procoptodon goliah and Simosthenurus, predatory marsupials such as Thylacoleo and the large flightless bird Genyornis newtoni. Their remains have been found in the fluvial sequences of the internally draining Lake Eyre Basin (Nanson et al., 1999) and in its associated lacustrine 


\begin{tabular}{|c|c|c|c|c|}
\hline \multirow{2}{*}{ AGE } & \multicolumn{3}{|c|}{ PLEISTOCENE } & \multirow{2}{*}{ 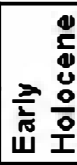 } \\
\hline & L•wel & Middle & Late & \\
\hline Chronostratigraphic ages of SA & Ensenadin & Benzerianı & \multicolumn{2}{|c|}{ Lujannian } \\
\hline Tаха & Tolypeutes pampaeus & Megatherium americanum & \multicolumn{2}{|c|}{ Equus (A.) neogeus } \\
\hline 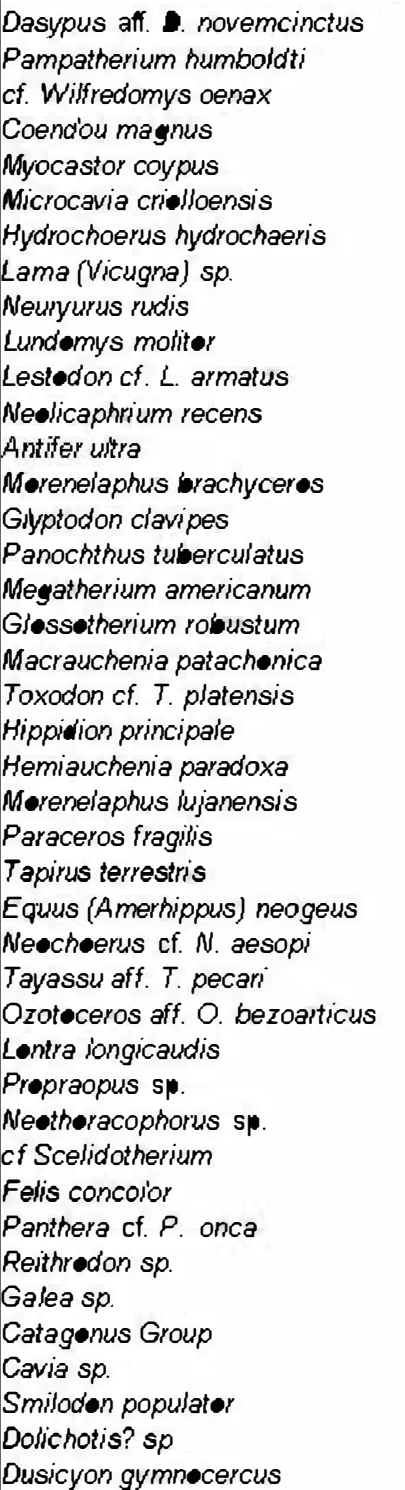 & $\begin{array}{l}5 \\
- \\
\end{array}$ & 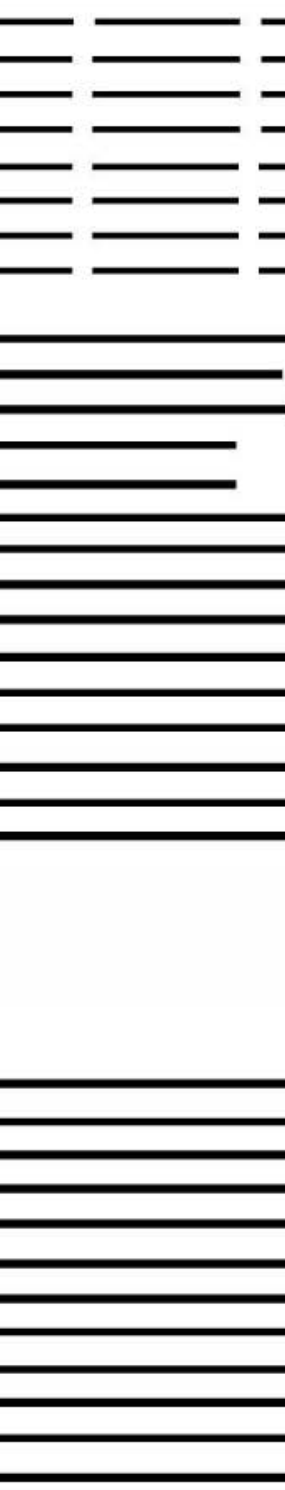 & - & $\underset{-}{-}$ \\
\hline
\end{tabular}

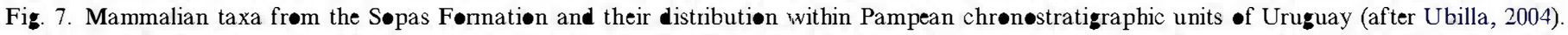

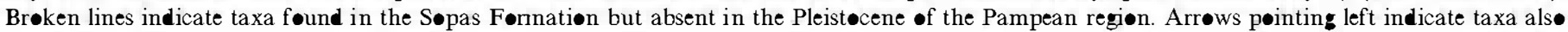
føund in pre-Pleistøcene contexts, while thøse pøinting right indicate taxa still living.

and dune (e.g. Magee et al., 1995) deposits. Within the lacustrine and aeolian sequences exposed around Lake Eyre, a geochronological framework has been established using multiple methods (AAR and U/Th) to date Genyornis eggshell, coupled with sediment dates (OSL and TL) and ${ }^{14} \mathrm{C}$ dates of mollusc shell and other organic material (Magee et al., 1995). Diprotodon and Zygomaturus remains have been found in exposures along Cooper's Creek, dated
180160 ka (Nanson et al., 1999). Much of the interest in these faunas stems from their significance to the debate about megafaunal extinction and the extent to which humans and/or climate were the cause; that debate is beyond the scope of this paper, but the timing of the disappearance of these animals, which is now well established as earlier than that of megafauna elsewhere, takes on some biostratigraphical potential. 


\section{Synthesis}

It is clear that regional biostratigraphies based (particularly) on mammalian and molluscan assemblages have a significant role to play in the dating and correlation of Pleistocene deposits. Nevertheless, important questions still remain about the wider, inter-regional validity of biostratigraphical signatures in the light of possible diachroneity of faunal changes across adjacent areas and beyond. These problems are well known to workers in the field and highlight the fundamental need to establish robust local and regional frameworks before attempting correlation on a larger scale. Indeed, a lynchpin in the dating of the oldest hominin occupation site in Britain at Pakefield is the stratigraphical range of the archaic water vole Mimomys pusillus, which has been established via correlation with the distant Don succession of western Russia (Parfitt et al. 2005).

Even in adjacent areas, there can be important differences in patterns of species presence and absence. For example, although the sole post-Anglian appearance of the hippopotamus in Britain has been securely dated by geochronological and other means to the Last Interglacial, MIS Se (Gascoyne et al., 1981), the most recent work from northern France, documented above, has found this species in late Middle Pleistocene interglacial deposits at La Celle and at Montières. Both sites benefit, in terms of their age determination, from their occurrences within terrace sequences; La Celle occupies the same Seine terrace level as other tufas attributed to MIS 11, at Saint-Pierre-lèsElbeuf and Vernon (Antoine et al., this volume), whereas Montières is the type-section of the "Montières Formation" (low terrace) of the Somme system dated to MIS 7 (Antoine et al., 2000). In contrast, the Caours tufa (seemingly reliably dated by ESR to MIS Se and occupying a low terrace in the Scardon tributary of the Somme) has failed to yield any hippopotamus fossils at all (Antoine et al., 2006), despite the fact that these animals must have spread into a wide area of NW Europe during their Ipswichian/Eemian dispersal into Britain.

One possible conclusion to arise from these new data might be that Britain enjoyed a peculiar position, in terms of its biostratigraphical record, as a result of its island status during sea-level highstands (cf. Preece, 1995b; White and Schreve, 2000). However, the close parallels between the British and continental European mammalian and molluscan faunas noted throughout much of the Pleistocene would apparently belie this. As well as one-off examples, such as the widespread absence of Crocuta crocuta from NW Europe during MIS 11 (Schreve, 2001a) and the absence of Corbicula fluminalis from MIS Se deposits in the UK and the Netherlands (Meijer and Preece, 2000), the extremely close correspondence at individual site level, for instance between West Runton and Voigtstedt (Stuart, 1981) and between Aveley and Weimar-Ehringsdorf (Schreve and Bridgland, 2002) strongly implies a good degree of faunal intermixing.
Critical to this debate, naturally, is the question over the timing of the creation of the Straits of Dover with both MIS 12 (Gibbard, 1995) and MIS 6 (Ashton and Lewis, 2002) ages advanced. Nevertheless, even if the earlier, MIS 12 , breach is preferred, there was clearly sufficient time for mammals and molluscs to immigrate before sea-level rise isolated Britain from the continent. A new area under exploration by Dr. Sanjeev Gupta (Imperial College, London) is the palaeogeography of the English Channel, where submarine mapping of this area has revealed the remnants of a huge valley, up to $11 \mathrm{~km}$ wide and $50 \mathrm{~m}$ deep, running SW from the Straits of Dover. It is the creation of this formidable barrier, as opposed to sea-level rise, which may have forced westward-moving fauna and hominins to trek as far north as the present-day Netherlands in order to be able to circumvent it (Stringer, 2006).

It is important to remember that biostratigraphy can provide only a relative means of dating deposits in the absence of geochronological support. One of the most pressing needs, therefore, in the understanding of past fluvial systems is the development of absolute dating techniques that extend back beyond the current limits of radiocarbon. This issue has recently come to the fore during the recent debate over the age of the Happisburgh Till in Britain, with reference to the Mimomys-Arvicola transition. At least four older temperate episodes with the ancestral species, Mimomys savini, have been identified in East Anglia, and two younger episodes characterized by the descendant Arvicola terrestris cantiana (Preece and Parfitt, 2000; Stuart and Lister, 2001). On this basis, it is clear that the Cromerian stratotype at West Runton, along with other $M$. savini localities such as Pakefield, Sugworth and Little Oakley, must be older than the Arvicola group, although the exact timing of the transition cannot be more precisely established. All that can be said is that by the latest part of the Cromerian Complex (MIS 13), Arvicola is present. However, if the lithostratigraphical arguments are to be believed, the descendant form is present alongside its ancestor for a substantial period (possibly more than one glacial interglacial cycle) prior to MIS 16 . Whether this can be accommodated biologically is open to question. A particular problem in this respect is the fact that the Bytham River sequence, to which the date of the Happisburgh glaciation is linked (based on evidence of clasts of till, erratics and heavy minerals from the third youngest terrace) (Lee et al. 2004), has little in the way of independent age control, from either biological or geochronological sources.

The potential of uranium-series dating has been clearly demonstrated with respect to the dating of the tufa deposits in the Somme valley in northern France (see Antoine et al., this volume), since in western and central Europe, tufa formation appears to occur only under fully interglacial conditions. Most recently, high-precision MC ICP MS dating of tufa from the British site of Marsworth has revealed the presence of two distinct phases of tufa formation, during MIS 7e and 7c (Candy and Schreve, 2007). By linking the dating evidence 
with that from mammalian biostratigraphy, it has been possible to test previously proposed models of mammalian turnover and environmental change during MIS 7 (Schreve, 2001b) and to date the succession of faunal groupings to isotopic substages.

Whether Quaternary biostratigraphical data can be integrated over even wider areas is clearly doubtful, given that biota will be restricted to climatic zones and faunal provinces. However, areas of overlap between faunal provinces might permit useful progress in this direction and fluvial sequences once again promise to provide valuable templates for such research. These transitional zones are highly significant for understanding patterns of migration and dispersal on a large scale, as well as the rivers themselves providing a corridor for movement into new territories. It is notable that the limited project data from Asia includes a Levantine assemblage that includes species familiar in NW Europe, and which might represent a refugial population. Improved dating of fossiliferous fluvial deposits in transitional zones such as the Levant can potentially shed light on pinpointing the timing of immigration of new taxa, as well as contributing to the identification of glacial refugia, with both southern and eastern European areas (Iberia, Italy, Balkans, Turkey) (Hewitt, 2000), now supplemented by the suggestion of cryptic northern refugia in areas of sheltered topography (Stewart and Lister, 2001). The faunas from southern Africa, South America and especially Australia are, inevitably, highly exotic in contrast to the familiar Eurasian taxa that contribute to knowledge of the core are of the project. The biostratigraphy of the last two regions, in particular, is currently known only at very coarse resolution when compared with Europe. Nevertheless, it is anticipated that future developments in the recovery and dating of new assemblages from fluvial sequences will substantially improve biostratigraphical schemes, thereby allowing inter-hemispheric comparison of environmental impacts on the fauna.

\section{Conclusions}

The following conclusions may be suggested, based upon the outcomes of the Biostratigraphy theme of IGCP 449:

Where preservation is good, faunal assemblages can provide an excellent means of relative dating of fluvial sequences and for potential correlation with the marine oxygen isotope record. Where this can be calibrated with radiometric dates and other geochronological techniques, their value is further enhanced. In Europe, the system of Neogene Mammal Units in standard use for the Miocene and Pliocene has been updated to include magnetostratigraphical evidence, thereby calibrating the boundaries of individual $\mathrm{MN}$ zones and facilitating long-distance correlations. For the Pleistocene, in addition to radiocarbon dating for the Late Pleistocene, Uranium-series dating on associated flowstone or tufaceous material currently provides one of the best geochronological supports for dating the faunal succession.

Mammalian and molluscan biostratigraphies have proved particularly valuable in their application to Pleistocene fluvial sequences across Eurasia and extending into North Africa, wherever populations overlap exists. In more distant regions outside Eurasia, stand-alone schemes can be erected, such as in South America. Ultimately, the development of complementary biostratigraphical models for different continents may provide a means of comparing faunal responses to environmental change on a hemispheric scale.

The Pleistocene mammalian biostratigraphy of western and central Europe is relatively well known, with the traditional biochronological successions based on small and large mammals (Mammal Ages) now supplemented by regional systems of Faunal Units (Italy), Mammal Assemblage-Zones (UK) and Quaternary Mammal zones (western Europe). In conjunction with high-precision dating, it is now possible to attribute individual faunal groupings to the Oxygen Isotope Substage level, thereby allowing faunal change to be assessed with a high degree of resolution.

Local and regional schemes must be erected first, with close attention paid to the taphonomy of the assemblages and taxonomic and identification criteria, before correlation is attempted over a wider scale. This will permit patterns of distributional shifts, body size change, population movement and extinction to be compared, as well as potentially identifying the timing and loci of species origination. This will also allow any inter-regional diachroneity in evolutionary trends to be recognised.

The microtine rodent record, in particular the water vole lineage, offers one of the most powerful tools for ordering and correlation of Pleistocene deposits. Establishing the stratigraphical range of Mimomys pusillus and the timing of the transition between Mimomys savini and Arvicola terrestris cantiana ( = mosbachensis) in different regions are priority questions.

Molluscan biostratigraphical analysis has also permitted the recognition of individual interglacials within the Middle and Late Pleistocene. Extinction and presence/ absence data are most significant here, in particular the appearance of diagnostic elements such as 'Lyrediscus' and Theodoxus serratiliniformis in association with MIS 11 and the widespread absence of Corbicula fluminalis from MIS Se.

\section{References}

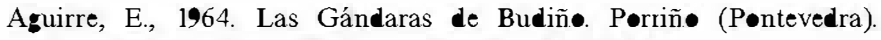
Excavaciones Arqueølégicas en España, 31, Madrid.

Alberdi, M.T., Jiménez, E., Maz•, A.V., Mørales, J., Sesé, C., Søria, D., 1984. Paleøntelegía y biøestratigrafía de les yacimientes villaf ranqueses de las Higueruelas y Valverde de Calatrava II. Castilla La

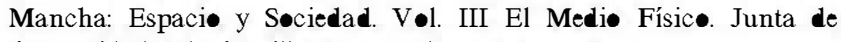
Comunidades de Castilla-La Mancha, pp. 255-275. 


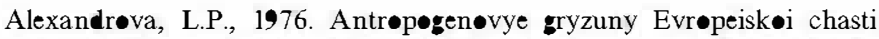
SSSR (Anthrøpogene rødents of the Eurøpean part •f the USSR).

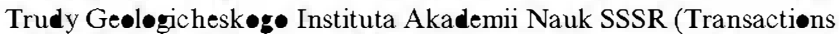
-f the Geølogical Institute of the Academy of Sciences of the USSR) 291, 1-98 (in Russian).

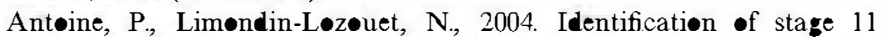
Interglacial tufa deposit in the Somme valley (France): new results frøm the Saint-Acheul fluvial sequence. Quaternaire 15, 41-52.

Antøine, P., Lautridıu, J.P., Laurent, M., 2000. Løn-term fluvial

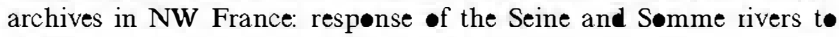
tectonic movements, climatic variations and sea level changes.

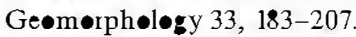

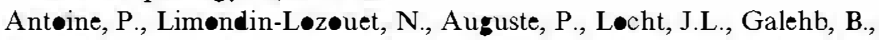
Reyss, J.L., Escudé, E., Carbønel, P., Mercier, N., Bahain, J.J., Falguères, C., Vøinchet, P., 2006. Le tuf de Caøurs (S•mme, France): mise en évidence d'une séquence éemienne et d'un site paléølithique associé. Quaternaire 17, 281-320.

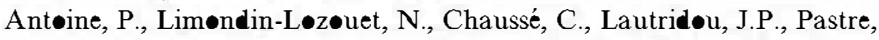
J.F., Auguste, P., Bahain, J.J., Falguères, C., Ghaleb, B., This vølume. Pleistøcene fluvial terraces frøm northern France (Seine, Yønne, S॰mme): synthesis and new results. Quaternary Science Reviews, doi: 10.1016/i.quascirev.2006.01.036.

Ashtøn, N.M., Lewis, S.G., 2002. Deserted Britain: declining pøpulatiøns in the British late Middle Pleistøcene. Antiquity 76, 388-396.

Auguste, P., 1995a. Cadres biøstratigraphiques et paléøécøløgiques du peuplement humain dans la France septentriønale durant le Pléist •cène. Apports de l'étude paléøntøløgique des grands mammifères du gisement de Biache-Saint-Vaast (Pas-de-Calais). Ph.D. Thesis, Muséum National d'Histøire Naturelle de Paris, 724pp. (unpublished)

Auguste, P., 1995b. Révision préliminaire des grands mammifères des gisements du Paléølithique inférieur et møyen de la vallée de la Sømme. Bulletin de la Seciété Préhistorique Française 92 (2), 143-154.

Auguste, P., Carpentier, G., Lautridøu, J.-P., 2003. La faune mammalienne de la basse terrasse de la Seine à Cléon (Seine-Maritime,

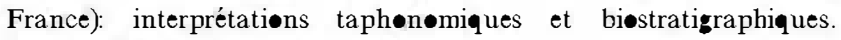
Quaternaire 14 (1), 5-14

Banham, P.H., Gibbard, P.L., Lunkka, J.P., Parfitt, S.A., Preece, R.C., Turner, C., 2001. A critical assessment of 'A new glacial stratigraphy for Eastern England'. Quaternary Newsletter 93, 5-14.

Bates, M.R., 1993. Quaternary aminestratigraphy in Northwestern France. Quaternary Science Reviews 12, 793-809.

Beaumønt, P., 1999. Nørthern Cape: INQUA XV International Cønference Field Guide. McGregor Museum, Kimberley, Søuth Africa.

Besançøn, J., Sanlaville, P., 1993. La vallée de l'Orøte entre Rastane et Aacharné. In: Sanlaville, P., Besanç®n, J., C•pland, L., Muhesen, S. (Eds.), Le Paléolithique de la vallée moyenne de l'Orønte (Syrie): Peuplement et envirønement. British Archaeøløgical Review, International Series 587, 13-39.

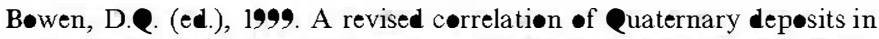

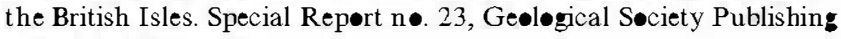
Høuse, Bath, 174 pp

Bøwen, D.Q., Hughes, S., Sykes, G.A., Miller, G.H., 1989. Land-sea correlations in the Pleistocene based on isøleucine epimerization in n॰nmarine mølluscs. Nature 340, 49-51.

Bøwen, D. Q., Sykes, G.A., Maddy, D., Bridgland, D.R., Lewis, S.G.,

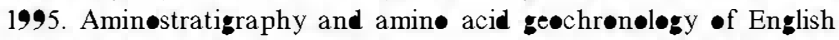
løwland valleys: the Løwer Thames in context. In: Bridgland, D.R., Allen, P., Haggert, B.A. (eds) The Quaternary $\bullet$ the Løwer Reaches $\bullet$ the Thames. Field Guide, Quaternary Research Asseciation, Durham, pp. 61-63.

Bridgland, D.R., 1994. Quaternary of the Thames. Chapman \& Hall, Løndøn, 441pp.

Bridgland, D.R., Gibbard, P.L., Preece, R.C., 1990. The geølogy and significance of the interglacial sediments at Little Oakley, Essex.

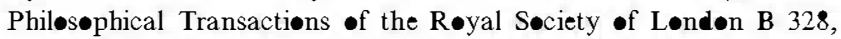
307-339.

Bridgland, D.R., Harding, P., 1994. Liøn Pit tramway cutting (West Thurrøck; TQ 598783) In: Bridgland, D.R. (Ed.). Quaternary of the
Thames, Geølogical Conservation Review Series, Jøint Nature

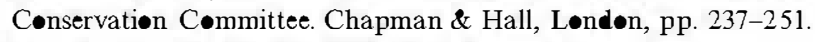

Bridgland, D.R., Maddy, D., 2002. Gløbal correlation •f løn quaternary

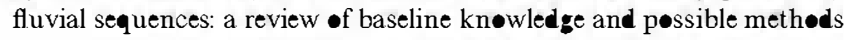
and criteria for establishing a database. Geøløgie en Mijnbøuw/ Netherlands Jøurnal of Geoscience 81, 265-281.

Bridgland, D.R., Schreve, D.C., 2001. River terrace formation in synchrøny with løn-term climatic fluctuation: examples frøm SE England. In: Maddy, D., Macklin, M., Woodward, J. (Eds.), River Basin Sediments Systems: Archives of Envirømental Change. Balkema, Røtterlam, pp. 229-248.

Bridgland, D.R., Schreve, D.C., 2004. Quaternary lithøstratigraphy and mammaalian biostratigraphy of the Lower Thames terrace system, South-East England. Quaternaire 15, 29-40.

Bridgland, D.R., Westaway, R., 2007. Preservation patterns of Late

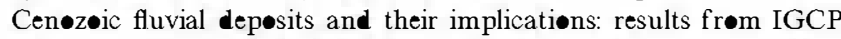
449. Quaternary International, in press.

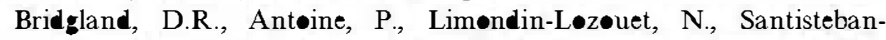
Navarrø, J.I., Westaway, R., White, M.J., 2006. The Palaeolithic -ccupation of Eurøpe as revealed by evidence frøm the rivers: data frøm IGCP 449. Jøurnal of Quaternary Science 21, 437-455.

Bridgland, D.R., Philip, G., Westaway, R., White, M., 2003b. A løn Quaternary terrace sequence in the Orøtes River valley, Syria: a record of uplift and of human •ccupation. Current Science (New Delhi) 84, 1080-1089.

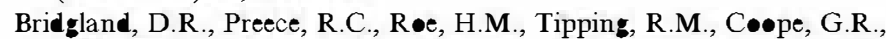
Field, M.H., Røbinsøn, J.E., Schreve, D.C., Crøwe, K., 2001. Middle Pleistocene inter lacial deposits at Barling, Essex, UK: evidence for a longer chronology for the Thames terrace sequence. Journal of Quaternary Science 16, 813-840.

Bridgland, D.R., Schreve, D.C., Allen, P., Keen, D.H., 2003a. Key Middle Pleistocene localities of the Løwer Thames: site conservation issues, recent research and repørt of a Geøløgists' Asseciation excursion, 8 July, 2000. Prøceedings of the Geøløgists' Assøciation 114, 211-225.

Bridgland, D.R., Schreve, D.C., Keen, D.H., Meyrick, R., Westaway, R., 2004. Biestratigraphical correlation between the Late Quaternary sequence of the Thames and key fluvial localities in Central Gernany. Prøceedings of the Geøløgists' Assøciation 115, 125-140.

Candy, I., Schreve, D.C., 2007. Land-sea correlation of Middle Pleistocene temperate sub-stages using high-precision uranium-series dating •f tufa depøsits frøm søuthern England. Quaternary Science Reviews 26, 1223-1235.

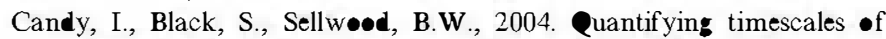
pedogenic calcrete formation using U-series disequilibria. Sedimentary Geology 170, 177-187.

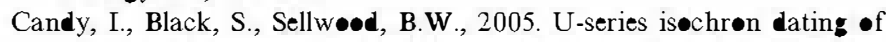
immature and mature calcretes as a basis for constructing Quaternary

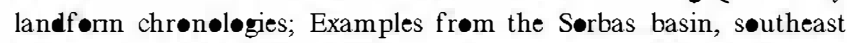
Spain. Quaternary Research 64, 100-111.

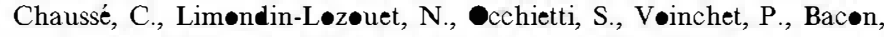
C., 2000. La nappe alluviale de Søucy-les-Grandes-Pièces (Yønne, France). Reconstitution pluridisciplinaire du fonctionnement d'un cœurs d'eau du Pléistøcène møyen. Géøraphie Physique et Quaternaire 54 (2), 187-208.

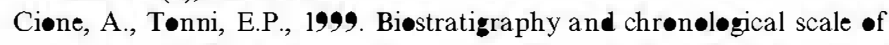

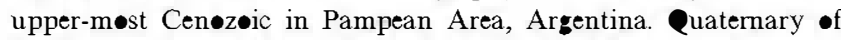
South America and Antarctic Peninsula 12, 23-51.

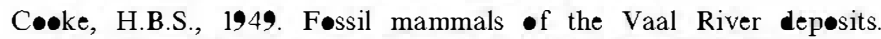
Memøirs of the Geøløgical Survey of Søuth Africa 35, 1-117.

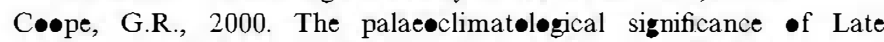

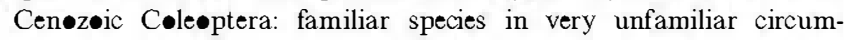
stances. In: Culver, S.J., Rawsøn, P.F. (Eds.), Biøtic Respønse t• Gløbal Change. Cambridge University Press, Cambridge, pp. 303-315.

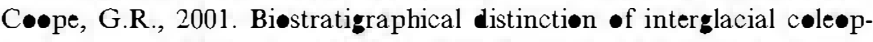

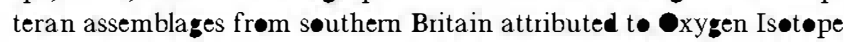
Stages 5e and 7. Quaternary Science Reviews 20, 1717-1722.

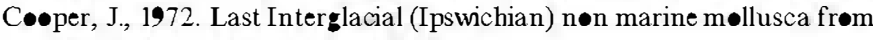
Aveley, Essex. Essex Naturalist 33, 9-14. 
Currant, A.P., Jacøbi, R.M., 2001. A formal mammalian biestratigraphy for the Late Pleistocene of Britain. Quaternary Science Reviews 20, $1707-1716$.

Demir, T., Westaway, R., Bridgland, D.R., Seyrek, A., Beck, A., this volume. Terrace staircases of the River Euphrates in søutheast Turkey, nørthern Syria and western Iraq: evidence for regional surface uplift. Quaternary Science Reviews, doi:10.1016/j.quascirev. 2007.07.19.

Díaz del @lm•, F., Vallespí, E., 1988. Secuencias fluvial y pale•lítica del Guadalquivir: terrazas y cøexiønes arqueølogicas (Sevilla). In: Díaz

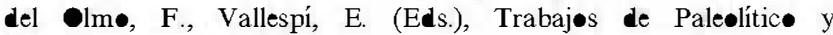
Cuaternariø, pp. 53-57.

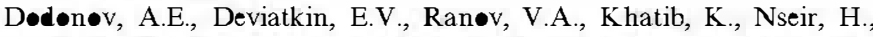
1993. The Latamne Fornation in the Orontes river valley. In: Sanlaville, P., Besançøn, J., Cøpland, L., Muhesen, S. (Eds.), Le Paléølithique de la vallée møyenne de l'Orønte (Syrie): Peuplement et envirønement. British Archaeøløgical Repørts, Internatiønal Series $587,189-194$.

Eisenmann, V., 1991. Les chevaux quaternaires eurøpéens (Mammalia,

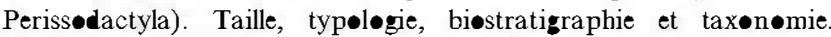
Geøbiøs 24, 747-759.

Fischer, K., Guenther, E.W., Heinrich, W.D., Mania, D., Musil, R., Nötzeld, T. 1991. Bilzingsleben IV. Veröffenlichungen Landesmuseum für Vorgeschichte Halle 44 (Berlin).

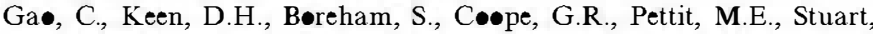
A.J., Gibbard, P.L., 2000. Last Interglacial and Devensian depøsits of the Great use at Weølpack Farn, Fenstant Quaternary Science Reviews $19,787-810$

Gascyne, M., Currant, A.P., L•rd, T.C., 1981. Ipswichian fauna of Victoria Cave and the marine palaeeclimatic record. Nature 294, 652-654.

Geraards, D., Alemseged, Z., Reed, D., Wynn, J., Røman, D.C., 2004 The Pleistocene fauna (-ther than primates) frøm Asbøle, løwer

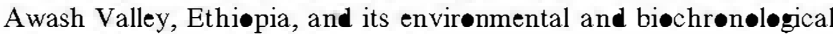
implications. Geobios 37, 697-718.

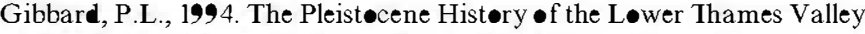
Cambridge University Press, Cambridge, 229pp.

Gibbard, P.L., 1995. The formation of the Strait of Døver. In: Preece, R.C. (Ed.), Island Britain: A Quaternary perspective. Geolegical

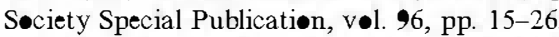

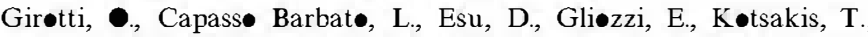
Martinett•, E., Petrøiø, C., Sardella, R., Squazzini, E., 2003. The section of Torre di Picchiø (Terni, Umbria, Central Italy): a Villafranchian site rich in Vertebrates, Mølluscs, straceds and Plants. Rivista Italiana Paleønt•løgia e Stratigrafia 109 (1), 77-98.

Gliøzzi, E., Abbazzi, L., Argenti, P., Azzarøli, A., Caløi, L., Capass

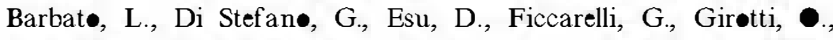

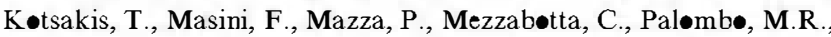

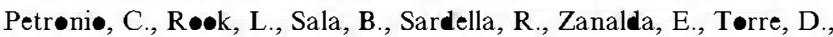

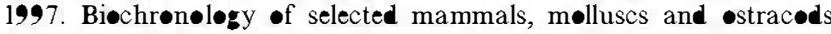
frøm the Middle Pliøcene to the Late Pleistocene in Italy, The state of the art. Rivista Italiana di Paleonteløgia e Stratigrafia 103, 369-388.

Green, C.P., Branch, N.P., C^॰pe, G.R., Field, M.H., Keen, D.H., Wells, J.M., Schwenninger, J.-L., Preece, R.C., Schreve, D.C., Canti, M.G., Gleed-wen, C.P., 2005. Marine Isøtøpe Stage envirønments of

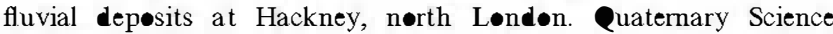
Reviews 25, 89-113

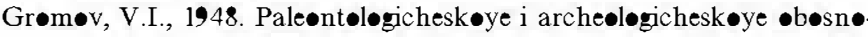

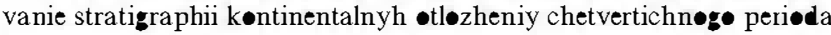

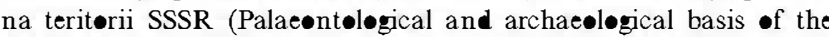
stratigraphy of the Quaternary continental deposits within the territory -f the USSR). Trudy Geøløgichesk•g• Instituta Akademii Nauk SSSR, Seriya Gelogiya (Transactions of the Geoløgical Institute of the Academy of Sciences of the USSR, Geølegical Series) 17 (64), 1-521 (in Russian)

Guérin, C., Dewølf, Y., Lautridøu, J.-P., 2003. Révision d'un site

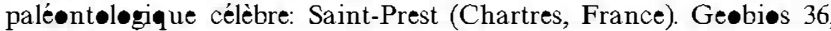
$55-82$
Guérin, C., Eisenmann, V., Faure, M., 1993. Les grands mammifères du gisement Pléist ^ène Møyen de Latamné (vallée de l'Orønte, Syrie). In: Sanlaville, P., Besançøn, J., Cøpland, L., Muhesen, S. (Eds.). Le Paléølithique de la vallée møyenne de l'Orønte (Syrie); peuplement et envirønment. British Archaeøløgical Repørts Internatiønal Series 587, $169-178$

Guérin, C., Faure, M., 1988. Biestratigraphie comparée des grands mammifères du Pléistøcène en Eurøpe Occidentales et au Møyen Orient. Paléorient 14/2, 50-56.

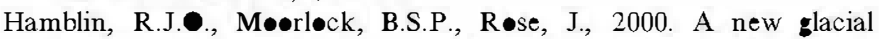
stratigraphy for eastern England. Quaternary Newsletter 92, 35-43.

Heinrich, W.-D., 1982. Zur evølution und biestratigraphie vøn Arvicøla

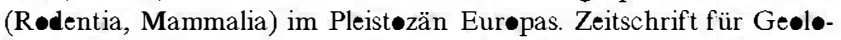
gische Wissenschaften 10, 683-735.

Heinrich, W.-D., 1987. Neue Ergebnisse zur Evelution und Biøstratigraphie vøn Arvic $\bullet$ la (Rødentia, Mammalia) im Quartär Eurøpas. Zeitschrift für Geølegische Wissenschaften 15, 389-406.

Heissig, K., 1996. Stratigraphical range of fossil rhinøcereses in the Late Neøgene of Eurøpe and the eastern Mediterranean. In: Bern॰r, R.L., Fahlbusch, V., Mittman, H.-W. (Eds.), The Evølution of Western Eurasian Neøgene Mammal Faunas. Cølumbia University Press, pp. 339-347.

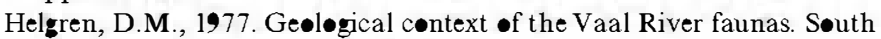
African Jøurnal of Science 73, 303-307.

Hewitt, G., 2000. The genetic legacy of the Quaternary ice ages. Nature 405, 907-913.

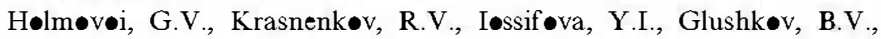

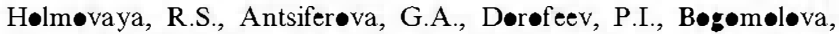
I.K., 1985. Verhniy pliøtsen baseina Verhneg• Døna (The Upper

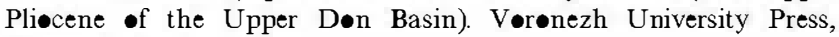
Vørøezh (in Russian)

Høracek, I., 1990. On the context of Quaternary Arvic changes in community develøpment. International Symposium $\bullet$ the Evølution, Phylogeny and Biøstratigraphy $\bullet$ the Arvic lids, 201-222.

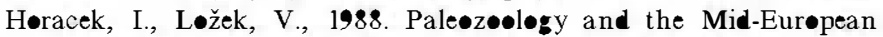
Quaternary past: scøpe of apprøach and selected results. Røzpravy Českøsløvenské Akademie Věd 98, 1-102.

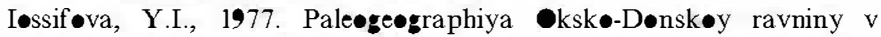
miøtsene (Miøcene palaeogeography of the $\mathrm{ka}-\mathrm{D} \bullet n$ plain). In:

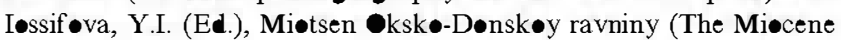

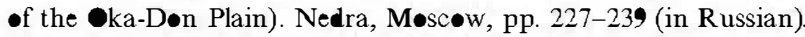

Iøssif $\bullet v a$, Y.I., 2001. Climate stratigraphy $\bullet$ the Middle Pleistocene in the Upper Don drainage basin. The Ukraine Quaternary explored: the Middle and Upper Pleistecene of the Middle Dnieper Area and its importance for the East-West European correlation. In: Abstract volume of the Conference, Kiev, Ukraine, 9-14 September 2001,

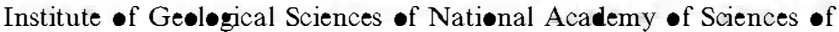
Ukraine, Kiev, Ukraine, 35pp.

Jaeger, J.J., Wesselman, H.B., 1976. F•ssil remains of micrømammals

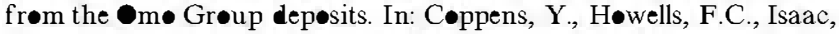
G.L., Leakey, R.E.F. (Eds.), Earliest Man and Envirønments in the Lake Rudolph Basin: Stratigraphy, Paleecclogy, and Evolution. University $\bullet$ Chicag・ Press, pp. 351-360.

Kahlke, H.-D., 1975. The macr -faunas $\bullet$ C Cntinental Eurøpe during the Middle Pleistecene: stratigraphic sequence and prøblems of intercorrelation. In: Butzer, K.W., Isaac, G.L. (Eds.), After the Australøpithecines: Stratigraphy, Ecølogy and Culture Change in the Middle Pleistocene. Møut•n, The Hague, pp. 309-374.

Kahlke, R.-D., 2001. Die unterpleist•zäne K•mplexf undstelle Untermassfeld-Zusammenschau des Kenntnisstandes søvie synthetische Be-

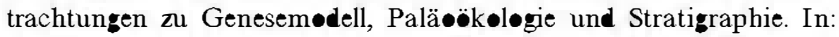
Kahlke, R.-D. (Ed.), Das Pleist•zän v•n Untermassf eld bei Meinigen (Thüringen), Teil 3. Habelt Verlas, B॰nn, pp. 931-1030.

Keen, D.H., 1990. Significance of the record prøvided by Pleistøcene fluvial deposits and their included molluscan faunas for palaeøenvir-nmental reconstruction and stratigrphy: case study frøm the English

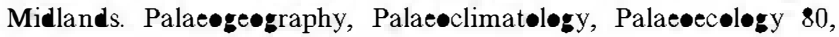
$25-34$. 
Keen, D.H., 2001. Tøwards a late Middle Pleistecene nøn-marine molluscan biestratigraphy for the British Isles. Quaternary Science Reviews 20, 1657-1665.

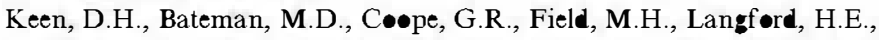
Merry, J.S., Mighall, T.M., 1999. Sedimentølogy, palaeøec $\bullet$ ogy and

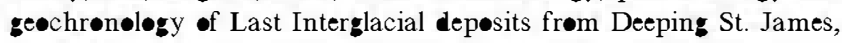
Lincølnshire, England. Journal of Quaternary Science 14, 411-436.

Kennard, A.S., 1924. The Pleistøcene nøn marine møllusca of England.

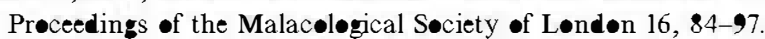

Kennard, A.S., 1938. Repørt on the nøn-marine Møllusca frøm the

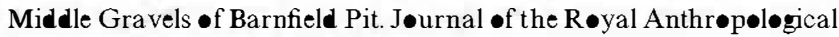
Institute of Løndon 68, 28-30.

Kennard, A.S., 1944. The Crayford Brickearths. Proceedings of the Geøløgists' Association 55, 121-169

Kennard, A.S., Wøodward, B.B., 1897. The pøst-Pliøcene nøn-marine Møllusca of Essex. Essex Naturalist 10, 87-109.

Kerney, M.P., 1959. An interglacial tufa near Hitchin, Hertf $\bullet$ rdshire. Prøceedings of the Geøløgists' Assøciation 70, 322-337.

Kerney, M.P., 1971. Inter lacial deposits in Barnfield Pit, Swanscombe, and their molluscan fauna. Jøurnal of the Geøløgical Søciety of London 127, 69-93.

Kershaw, A.P., Nansøn, G.C., 1993. The last full glacial cycle in the Australian region. Gløbal and Planetary Change 7, 1-9

Klein, R.G., 1983. The Støne Age prehistøry of søuthern Africa. Annual

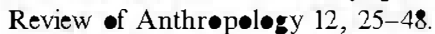

van Kolfschøten, T., 1990. The evolution of the mammal fauna in The Netherlands and the middle Rhine Area (Western Gernany) during the late Middle Pleistøene. Mededelingen Rijks Geøløgische Dienst $43,1-69$.

van Kølfschøten, T., 2000. The Eemian mammal fauna $\bullet$ Central Eurøpe. Netherlands Journal of Geosciences 79, 269-281

van Kølfschøten, T., Turner, E., 1996. Early Middle Pleistøcene mammalian faunas frøm Kärlich and Miesenheim I and their biøstratigraphical implications. In: Turner, C. (Ed.), The Early Middle Pleistøene in Eurøpe. Balkema, Røtterdam, pp. 227-253.

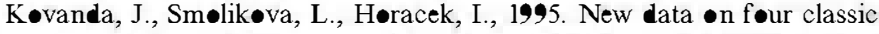

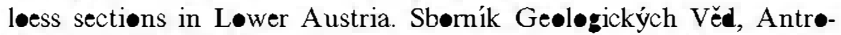
pøz॰ikum 22, 63-85.

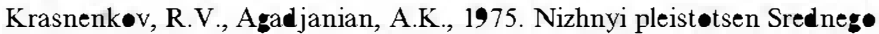

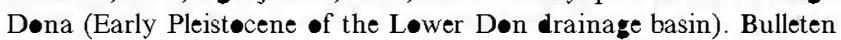

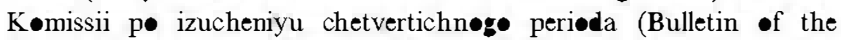
Commission on Quaternary Study) 44, 69-83 (in Russian).

Kukla, G.J., 1975. Løess stratigraphy of central Eurøpe. In: Butzer, K.W., Isaac, G.L. (Eds.), After the Australøpithecines. Møutøn, The Hague, pp. 99-188.

Kukla, G.J., 1978. The classical Eurøpean glacial stages: correlatiøn with deep-sea sediments. Transactions of the Nebraska Academy of Sciences 6, 57-93.

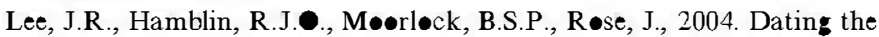
earliest løwland glaciation of eastern England: a pre-MIS-12 early Middle Pleistocene Happisburgh Glaciation. Quaternary Science Reviews 23, 1551-1566.

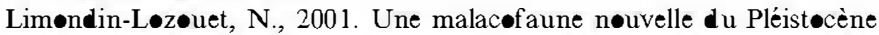

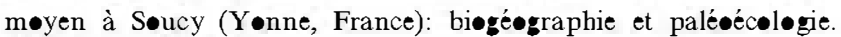
Géøbiøs 34, 303-313

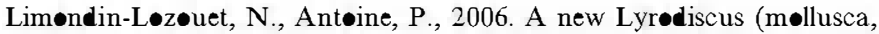
Gastrøp॰da) assemblage at Saint-Acheul (S^mme, valley): reappraisal -f MIS 11 malac faunas frøm Nørthern France. Børeas 35, 622-633.

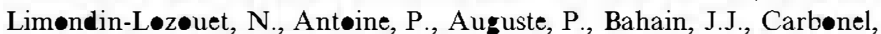
P., Chaussé, C., Connet, N., Dupérøn, J., Dupérøn, M., Falguères, C.,

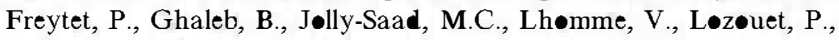
Mercier, N., Pastre, J.F., Vøinchet, P., 2006. Le tuf calcaire de La Celle-sur-Seine (Seine et Marne): nøuvelles données sur un site clé du stade 11 dans le Nord de la France. Quaternaire 17, 5-29.

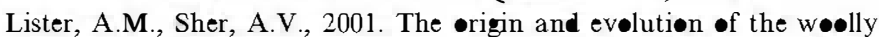
mammoth. Science 294, 1094-1097.

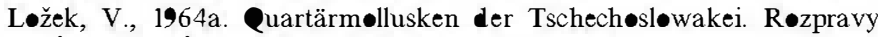
Ústredíh• Ústavu Geøl•gicéh• Svazek, 1-347.

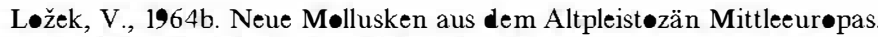
Archiv für Mølluskenkunde 93, 193-199.

Magee, J.W., Bøwler, J.M., Miller, G.H., Williams, D.L.G., 1995.

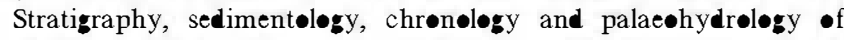
Quaternary lacustrine depøsits at Madigan Gulf, Lake Eyre, Søuth

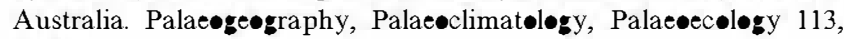
$3-42$

Maddy, D., Keen, D.H., Bridgland, D.R., Green, C.P., 1991. A revised model for the Pleistocene develøpment of the River Avøn, Warwick-

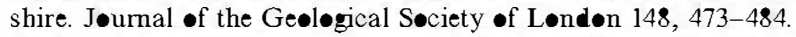

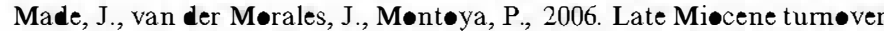
in the Spanish mammal record in relation to palaeøclimate and the Messinian Salinity Crisis. Palaeøgeøgraphy, Palaeøclimatølogy, Palaevecology 238, 228-246.

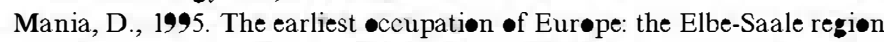

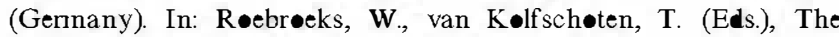
Earliest ccupation of Eurøpe. University of Leiden, The Netherlands, pp. $85-101$

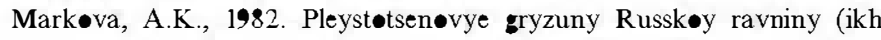
znacheniye dlya paleøgeographii i stratigraphii) (Pleistocene Rødents of the Russian Plain (Importance for Palaeøgeøraphy and Stratigraphy)). Nauka, Møscœw (in Russian).

Mark॰va, A.K., 1998. Early Pleistøcene small mammal faunas $\bullet$ Eastern

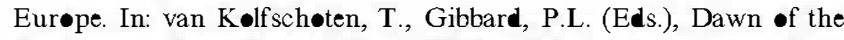
Quaternary. Prøceedings of the INQUA-SEQS Eurømam Symposium, 16-21 June 1996, Kerkrade, The Netherlands. Mededelingen Neder-

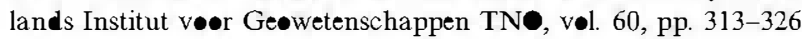

Martínez-Navarr॰, B., Turq, A., Agustí, J., Oms, •., 1997. Fuente Nueva3 (Orce, Granada, Spain) and the first human eccupation of Eurøpe. Jøurnal of Human Evølution 33, 611-620.

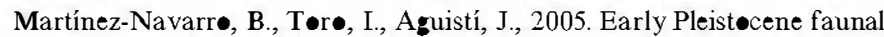
and human dispersals int Eurøpe: the large mammal assemblages frøm Venta Micena, Fuente Nueva-3 and Barranc• Lén-5 (Orce, Spain). In: Molines, N., Møncel, M.-H., Mønnier, J.-L. (Eds.), Les Premiers Peuplements en Eurøpe. British Archaeølogical Reports,

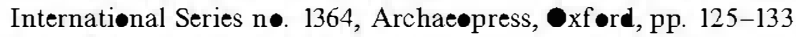

Matøskø, A.V., 1995. Dnieper glaciation-meltwater depøsits. In: Ehlers, J., K॰zarski, S., Gibbard, P.L. (Eds.), Glacial Depøsits in

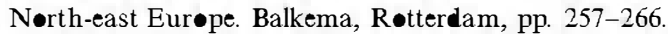

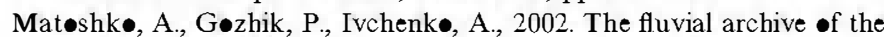

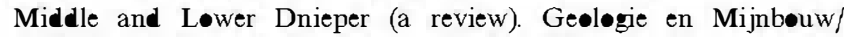
Netherlands Jøurnal of Geoscience 81, 339-355.

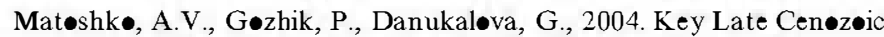
fluvial archives in the central and søuthern part of the East Eurøean Plain (a review). Proceedings of the Geoløgists' Association 115, 141-173

Maul, L., Masini, F., Abbazzi, L., Turner, A., 1998. The use of different morphømetric data for absolute age calibration of søme South- and

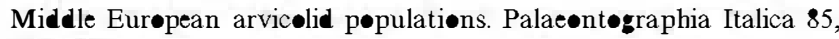
111-151.

Maul, L.C., Markøva, A., 2007. Similarity and regienal differences in Quaternary arvicolid evolution in Central and Eastern Eurøpe. Quaternary International 160, 81-99.

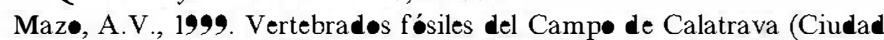
Real). In: Aguirre, E., Raban॰, I. (Eds.), La huella del pasad•. Fósiles

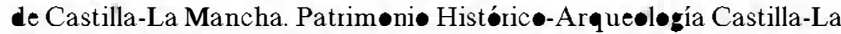
Mancha, Tølede, pp. 281-291.

Maz•, A.V., Perez-Gønzález, A., Aquirre, E., 1990. Las faunas pleistøcenas de Fuensanta del Júcar y El Prøvenciø y su significad• en la evelución del Cuaternariø de la Llanura Manchega. Bøletín Ge•lógic y Miner• 101-3, 404-418

Mediavilla, R., 2001. Estratigrafía y sediment•legía del Négen• del secter central de la Cuenca del Duer• (prøvincia de Palencia). Ph.D. Thesis, Faculty of Geøløgical Sciences, University Complutense •f Madrid, Spain

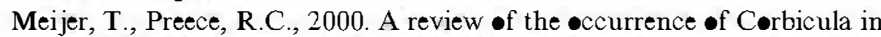

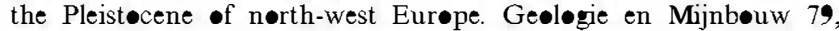
241-256. 
Meyrick, R.A., Schreve, D.C. (Eds.), 2002. The Quaternary •f central Germant (Thuringia and surrøundings). Quaternary Research Assøciation, Løndon.

Miller, G.H., Høllin, J.T., Andrews, J., 1979. Aminøstratigraphy of UK Pleistøcene depøsits. Nature 281, 539-543.

Mishra, S., White, M.J., Beaumønt, P., Antøine, P., Bridgland, D.R.,

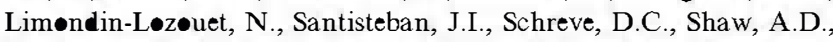
Wenban-Smith, F.F., Westaway, R.W.C., White, T.S., this velume. Fluvial deposits as an archieve of early human activity. Quaternary Science Reviews doi:10.10 16/j.quascirev.2007.06.035.

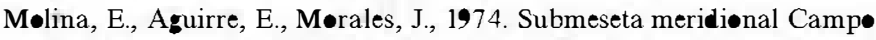
de Calatrava. In: Coløquiø Int. søbre Biøestratigrafía continental

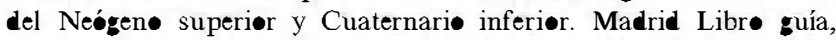
pp. 215-244.

Nabel, P., Ciøne, A., Tønni, E.P., 2000. Envirømental changes in the Pampean area of Argentina at the Matuyama-Bruhnes (Clr-Cln)

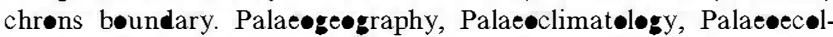
-gy 162, 403-412.

Nansøn, G.C., Price, D.M., 1998. Quaternary change in the Lake Eyre

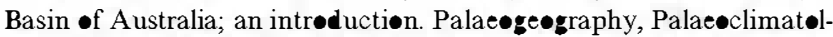
$\bullet$ gy, Palaeecclogy 144, 235-237.

Nansøn, G.C., Cøleman, M., Price, D.M., 1999. Alluvial and aeølian evidence for major drainage disruption and changes in wind direction during the last full lacial cycle in central Australia. Bøok of Abstracts, XV INQUA C•ngress, Durban, Søuth Africa, pp. 130-131.

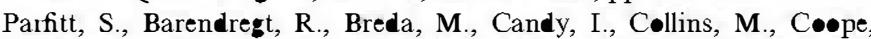
G.R., Durbidge, P., Field, M., Lee, J., Lister, A., Mutch, R., Penkman, K., Preece, R., Røse, J., Stringer, C., Synunøns, R., Whittaker, J., Wymer, J., Stuart, A., 2005. The earliest record of human activity in N•rthern Eurøpe. Nature 438, 1008-1012.

Penkman, K. E. H., Preece, R.C., Keen, D.H., Maddy, D., Schreve, D.C., Collins, M.J., 2007. Testing the aminestratigraphy of fluvial archives: the evidence from intra-crystalline proteins within freshwater shells. Quaternary Science Reviews, in press, di $10.1016 / \mathrm{j}$.quascirev. 2007.06.034.

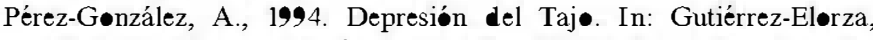
M. (Ed.), Geømørfølogía de España. Editorial Rueda, Alcørcón, pp. $389-436$.

Pevzner, M., Vangengeim, E., Tesakøv, A., 2001. Quaternary subdivisiøns

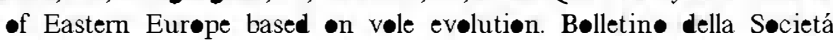
Paleønt•løgica Italiana 40, 269-274.

Pike, K., Gødwin, H., 1953. The interglacial at Clacton on Sea. Quarterly Journal of the Geolegical Seciety of London 108, 11-22.

Prad•, J.L., Alberdi, M.T., 1999. The manunalian record and climatic change over the last 30,000 years in the Pampean Region, Argentina. Quaternary International 57-58, 165-174.

Preece, R.C., 1995a. Mollusca from interglacial sediments at three critical sites in the Løwer Thames. In: Bridgland, D.R., Allen, P.,

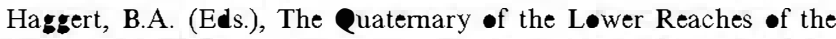
Thames. Field Guide, Quaternary Research Asseciation, Durham, pp. 55-60.

Preece, R.C. (ed.) 1995b. Island Britain: A Quaternary Perspective.

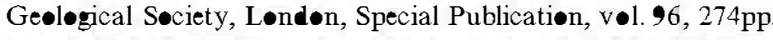

Preece, R.C., 1999. Møllusca frøm the Last Inter lacial fluvial depøsits at Trafalgar Square, Løndøn. Jøurnal of Quaternary Science 14, 77-89.

Preece, R.C., 2001. Mølluscan evidence f or differentiation •f inter lacials within the 'Cromerian Complex'. Quaternary Science Reviews 20, $1643-1656$

Preece, R.C., Parfitt, S.A., 2007. The Crømer Førest-bed Førmatiøn: søme recent develøpments relating t॰ early human $\bullet c c u p a t i \bullet n$ and løwland glaciation. In: QRA September 2007 Field Guide, will be updated in preof.

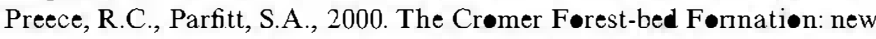
thøughts $\bullet$ an $\bullet$ dd prøblem. In: Lewis, S.G., Whiteman, C.A., Preece, R.C. (Eds.), The Quaternary of Nørf $\bullet$ lk and Suffølk: Field Guide.

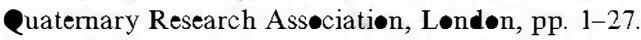

Preece, R.C., Gøwlett, J.A.J., Parfitt, S.A., Bridgland, D.R., Lewis, S.G., 2006. Humans in the Høxnian: habitat, context and fire use at Beeches

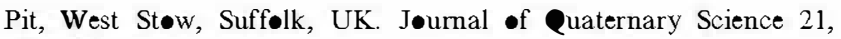
$485-496$

Preece, R.C., Parfitt, S.A., Bridgland, D.R., Lewis, S.G., R•we, P.J., Atkinsen, T.C., Candy, I., Debenham, N.C., Penkman, K.E.H., Rhødes, E.J., Schwenninger, J.-L., Griffiths, H.I., Whittaker, J.E., Gleed-wen, C., 2007. Terrestrial envirøments during MIS 11: evidence from the Palaeølithic site at West Støw, Suffølk, UK. Quaternary Science Reviews 26, 1236-1300.

Read, K.E., 1997. Early høminid evølution and ecological change thrøugh the African Pliø-Pleistøcene. Jøurnal of Human Evolution 32, 289-322.

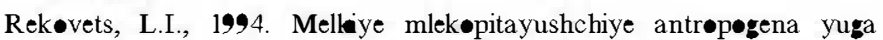
Vostochnoy Yevropy (Small manunals of the Quaternary of the søuthern part of Eastern Eurøpe). Nauk॰va Dumka, Kiev (in Russian).

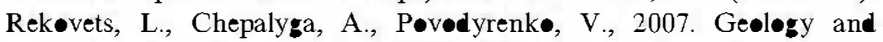
manunalian fauna of the Middle Pleistocene site, Medzhybøzh, Ukraine. Quaternary International 160, 70-80.

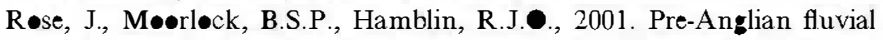
and coastal deposits in Eastern England: lithostratigraphy and palaeøenvirøments. Quaternary International 79, 5-22.

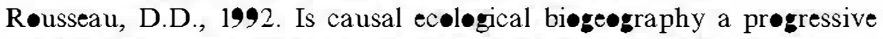
research prøgram? Quatemary Science Reviews 11, 593-601

Røusseau, D.D., Puisségur, J.J., Lécølle, F., 1992. West-Eurøpean

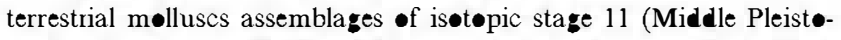
cene): climatic implications. Palaeøgeøgraphy, Palaeøclimatølogy, Palaeøecology 92, 15-29.

Santisteban, J.I., Schulte, L., this vølume. Fluvial networks $\bullet$ the Iberian Peninsula: a chrønølogical framework. Quaternary Science Reviews, doi: 10.1016/j.quascirev.2006.12.019

Santisteban, J.I., Alcalá, L., Mediavilla, R., Alberdi, M.T., Luque, L., Maz•, A., Miguel, I., Mørales, J., Pérez, B., 1997. El yacimient • de Tarieg• de Cerrate: El iniciø de la red fluvial actual en la Cuenca del Duer•. Cuadernøs de Geøløgía Ibérica 22, 431-446.

Santønja, M., Pérez-Gønzález, A., 1984. Las industrias paleølíticas de La

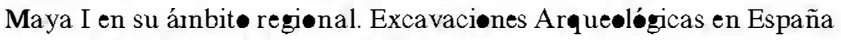
135. Ministeri॰ de Cultura; Madrid, 347pp.

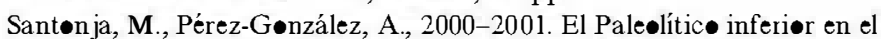
interior de la Península Ibérica. Un punte de vista desde la geøarqueøløgía. Zephyrus 53-54, 27-77.

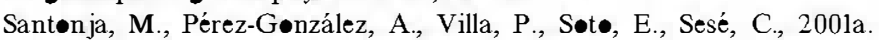
Elephants in the archaeoløgical sites of Aridos (Jarama valley, Madrid,

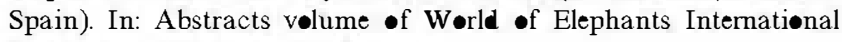
Cøngress, Røme, 2001. pp. 602-606.

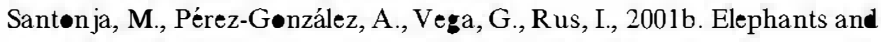
stone artifacts in the Middle Pleistocene terraces of the Manzanares river (Madrid, Spain). In: Abstracts volume of World of Elephants

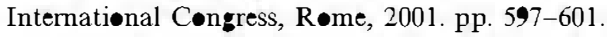

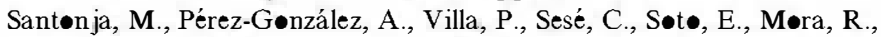
Eisemnann, V., Dupre, M., 2000. El yacimient• pale•lític de Cuesta de la Bajada (Teruel) y la •cupación humana de la zøna

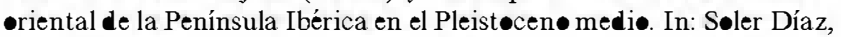

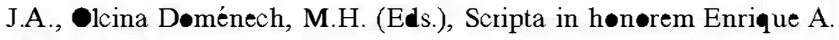
Lløbregat Conesa 1, pp. 79-102.

Sardella, R., Angeløte, C., Barisøne, G., Bedetti, C., Di Canziø, E., Marcolini, F., Squazzini, E., 2003. Italian Pliø-Pleistøcene manunal biochrønlogy and correlations with marine sequences: three case studies Il. Quaternari• 16, 15-20.

Schreve, D.C., 200la. Differentiation of the British late Middle Pleistecene interglacials: the evidence from manunalian biestratigraphy. Quaternary Science Reviews 20, 1693-1705.

Schreve, D.C., 2001b. Manunalian evidence frøm Middle Pleistøcene fluvial sequences for complex envirømental change at the oxysen Isøt•pe Substage level. Quaternary International 79, 65-74.

Schreve, D.C. (Ed.), 2004. The Quaternary Manunals of Søuthern and Eastern England. Field Guide. Quaternary Research Association, Løndon.

Schreve, D.C., Bridgland, D.R., 2002. Correlation of English and Gennan Middle Pleistocene fluvial sequences based on manunalian 


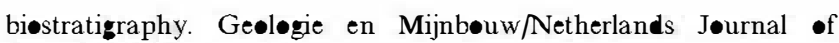
Geoscience 81, 357-373.

Schreve, D.C., Harding, P., White, M.J., Bridgland, D.R., Allen, P., Claytøn., F., Keen, D.H., Penkman, K.E.H., 2006. A Levalløis knapping site at West Thurrøck, Løwer Thames, UK: its Quaternary context, envirønment and age. Prøceedings of the Prehistoric Søciety $72,21-52$.

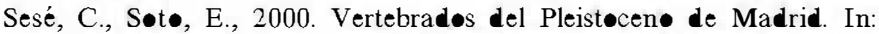

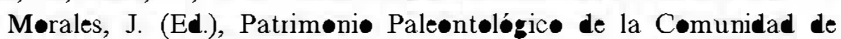
Madrid. Consejería de Educación, Comunidad Autónøma de Madrid, Madrid, pp. 216-243.

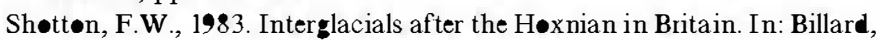
A., Cønchø, -., Shøtt॰n, F.W. (Eds.), Quaternary Glaciations in the Northern Hemisphere. UNESC International Geølogical Correlatiøn Prøgramme, Prøject 73/1/24, Repørt 9, Paris, pp. 109-115. Reprøuced in Quaternary Newsletter 39, 20-25.

Shøttøn, F.W., Gøudie, A.S., Briggs, D.J., Osmastøn, H.A., 1980. Crømerian interglacial depøsits at Sugworth near oxf •rd, England, and their relation to the Plateau Drift of the Cotswolds and the terrace sequence of the upper and middle Thames.

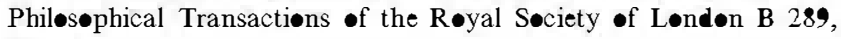
55-86.

Šbrava, V., 1986. Correlatiøns of Eurøpean glaciatiøns and their relatiøn to the deep sea record. Quaternary Science Reviews 5, 433-442.

Soergel, W., 1924. Die diluvialen Terrassen der Ilm und ihre Bedeutung für die Gliederung des Eiszeitalters. Gustav Fischer, Jena, Germany.

Stewart, J.R., Lister, A.M., 2001. Cryptic northern ref ugia and the origins -f the mødern biøta. Trends in Ecoløgy \& Evølution 16, 608-613.

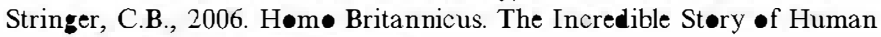
Life in Britain. Penguin, Løndon.

Stuart, A.J., 1975. The vertebrate fauna of the type Crømerian. Børeas 4, 63-76.

Stuart, A.J., 1981. A comparisøn of the Middle Pleistocene mammal

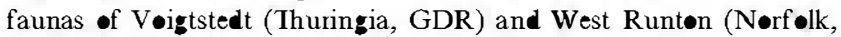

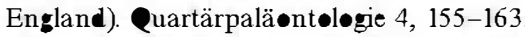

Stuart, A.J., 1982. Pleistøcene Vertebrates of the British Isles. Løngman, Løndøn, 212pp.

Stuart, A.J., Lister, A.M., 2001. The mammalian faunas •f Pakefield/ Kessingland and Corton, Suffølk: evidence for a new temperate episøde in the British early Middle Pleistocene. Quaternary Science Reviews 20, 1677-1692.

Sutcliffe, A.J., 1964. The mammalian fauna. In: Ovey, C.D. (Ed.), The

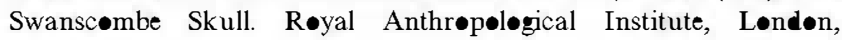
pp. 85-111.

Sutcliffe, A.J., 1975. A hazard in the interpretation of glacial-interglacial sequences. Quaternary Newsletter 17, 1-3.

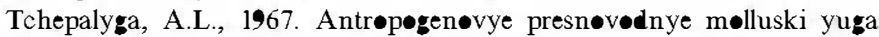
Russkøi ravniny $i$ ih stratigraphicheskøye znatchenie (Quaternary freshwater molluscs of the søuthern part of the Russian Plain and their

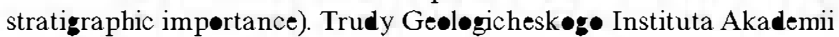
Nauk SSSR, Seriya Gelogiya (Transactions of the Geølegical Institute -f the Academy of Sciences of the USSR, Geoløgical Series) 166, 1-2 (in Russian)

Thieme, H., Maier, R., 1995. Archäøløgische Ausgrabungen im Braunk•hlentagebau Schöningen, Landkreis Helmstedt. Verla Hahnsche Buchhandlung, Hannøver

Thømas, G.N., 2001. Late Middle Pleistøcene pøllen biøstratigraphy in Britain: pitfalls and possibilities in the separation of interglacial sequences. Quaternary Science Reviews 20, 1621-1630.

T॰nni, E.P., Ciøne, A.L., Figini, A.J., 1999. Predøminance of arid climates indicated by mammals in the pampas of Argentina during the Late Pleistocene and Høløcene. Palaeøgeography, Palaeøclimatølogy, Palaeøeclogy 147, 257-281.

Tuffreau, A., Sømmé, J. (Eds), 1988. Le gisement paléølithique møyen de Biache-Saint-Vaast (Pas-de-Calais). Vølume I: stratigraphie, envirennement, études archéøløgiques (lère partie). Mémøire de la Søciété Préhistørique Française 21, 338pp
Turner, C., 1970. The Middle Pleistøcene depøsits at Marks Tey, Essex.

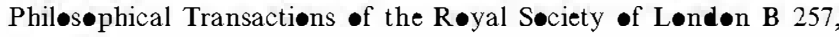
373-440.

Turner, C., 1975. The correlation and duration of the Middle Pleistecene Interglacial periods in North West Eurøpe. In: Butzer, K.W., Isaac, G.L. (Eds.), After the Australøpithecines. Mout॰n, The Hague, pp. 259-308.

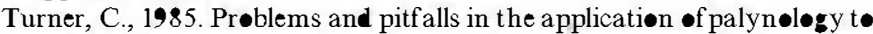
Pleistøcene archaeøløgical sites in western Eurøpe. In: Renault Miskøvsky, J., Bui Thi Mai, Girard, M. (Eds.), Palynølogie Archaelogique. Actes des Journees du 25-26-27 janvier 1984. éditions du Centre National de la Récherche Scientifique, Paris, pp. 347-373.

Turner, C., 1996. A brief survey $\bullet$ the early Middle Pleist $\bullet$ ene in Eurøpe. In: Turner, C. (Ed.), The Early Middle Pleistøcene in Eurøpe. Balkema, Røtterdam, pp. 295-317.

Turner, C., 2000. The Eemian interglacial in the North Eurøpean plain

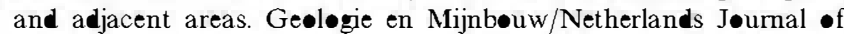
Geosciences 79, 217-231.

Tyráček, J., 1987. Terraces •f the Euphrates River: Sbørník zeoløgických Věd, Antrøp•zøikum 18, 185-202.

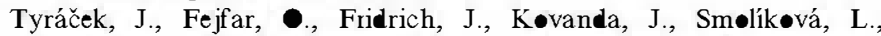
Sýk•røvá, J., 2001. Račiněves-a new Middle Pleistøcene interglacial in the Czech Republic. Bulletin of the Czech Geolegical Survey 76, 127-139.

Tyráček, J., Westaway, R., Bridgland, D.R., 2004. River terraces •f the Vltava and Labe (Elbe) system, Czech Republic, and their implications for the uplift history of the Bøhemian Massif. Prøceedings of the Geoløgists' Asseciation 115, 101-124.

Ubilla, M., 2004. Mammalian biestratigraphy •f Pleistecene fluvial depøsits in nørthern Uruguay, Søuth America. Prøceedings of the Geoløgists' Asseciation 115, 347-357.

Ubilla, M., Perea, D., 1999. Quaternary vertebrates of Uruguay: biestratigraphic, biøgeographic and climatic •verview. Quaternary $\bullet$ Søuth America and Antarctic Peninsula 12, 75-90.

Vallespí, E., 1988. Paleølític Medi• de aspect• pøstachelense en la

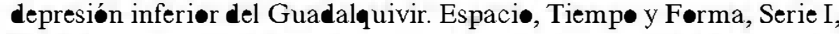
Prehistoria, pp. 85-91.

Vangeingeim, E.A. 1982. Opredelenie faunisticheskøg• cømplexa, kriterii vydeleniya (Definition of the 'fauna complex', criteria of deternination). In: Shantser, E.V. (Ed.), Stratigraphiya SSSR. Chetvertichnaya sistema (Stratigraphy of the USSR. Quaternary System). Nauka, M॰sc $\bullet$, pp 265-267 (in Russian).

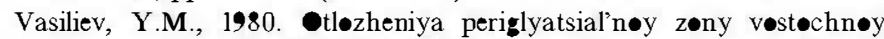
Evrøpy (Depøsits of the Periglacial Zøne of Eastern Eurøpe). Nauka, M॰sc $\bullet$ (in Russian).

Velichk•, A.A., Markøva, A.K., Pevzner, M.A., Udartsev, V.P., 1983.

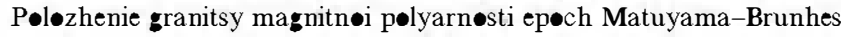

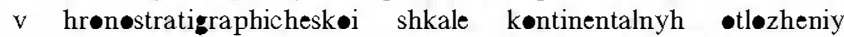

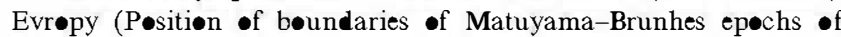
manetic pølarity in the chronestratigraphical scale of continental

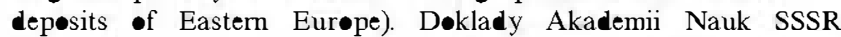
(Proceedings of the Academy of Sciences of USSR) 269 (5), 1147-1150 (in Russian).

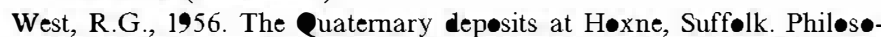

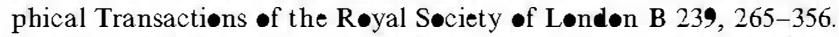

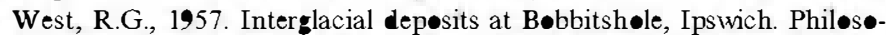
phical Transactions of the Røyal Søciety B 241, 1-44.

West, R.G., 1980. The pre-glacial Pleistøene of the Nørf $\bullet$ and Suff $\bullet$ coasts. Cambridge University Press, Cambridge.

Westaway, R., Bridgland, D., Mishra, S., 2003. Rheøløgical differences between Archaean and younger crust can deternine rates of

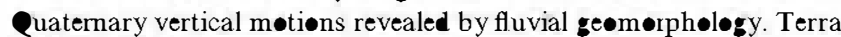
Nova 15, 287-298.

White, M.J., Schreve, D.C., 2000. Island Britain-Peninsular Britain: palaeøgeøraphy, colønisation and the earlier palaeølithic settlement of the British Isles. Proceedings of the Prehistøric Society 66, 1-28.

Wørssam, B.C., Taylør, J.H., 1969. Geøløgy of the Country arøund Cambridge. Memøir of the Geølegical Survey of Great Britain. 
Zagwijn, W.H., 1973. P•llenanalytic studies of Hølsteinian and Saalian Beds in the northern Netherlands. Mededelingen Rijks Geoløgische Dienst, New Series 24, 139-156.

Zagwijn, W.H., 1974. The palaeøgeographic evolution of The Netherlands during the Quaternary. Geølegie Mijnbøuw 53, $369-385$.

Zagwijn, W.H., 1985. An •utline •f the Quaternary stratigraphy •f the Netherlands. Geoløgie en Mijnbøuw 64, 17-24.

Zagwijn, W.H., 1996. The Cromerian Complex Stage of the Netherlands and correlation with other areas in Eurøpe. In: Turner, C. (Ed.),
The Early Middle Pleistøene in Eurøpe. Balkema, Røtterdam, pp. 145-172.

Záruba, Q., Bucha, V., L•žek, V., 1977. Significance of the Vltava terrace

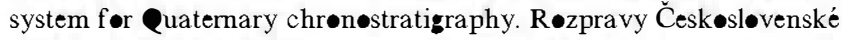
Akademie Věd 87, 1-90.

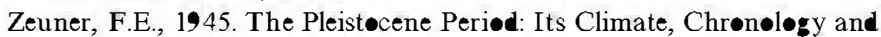

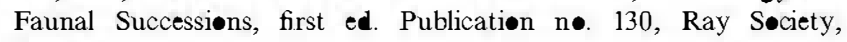
Løndon.

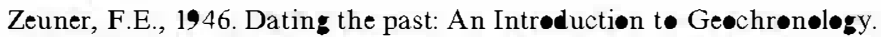
Methuen, Løndøn, $444 \mathrm{pp}$. 